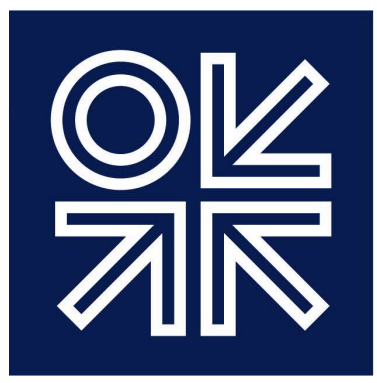

THE OXFORD

INSTITUTE

FOR ENERGY

STUDIES

September 2016

\title{
GCC-East Asia Relations in the Fields of Nuclear and Renewable Energy: Opportunities and Barriers
}

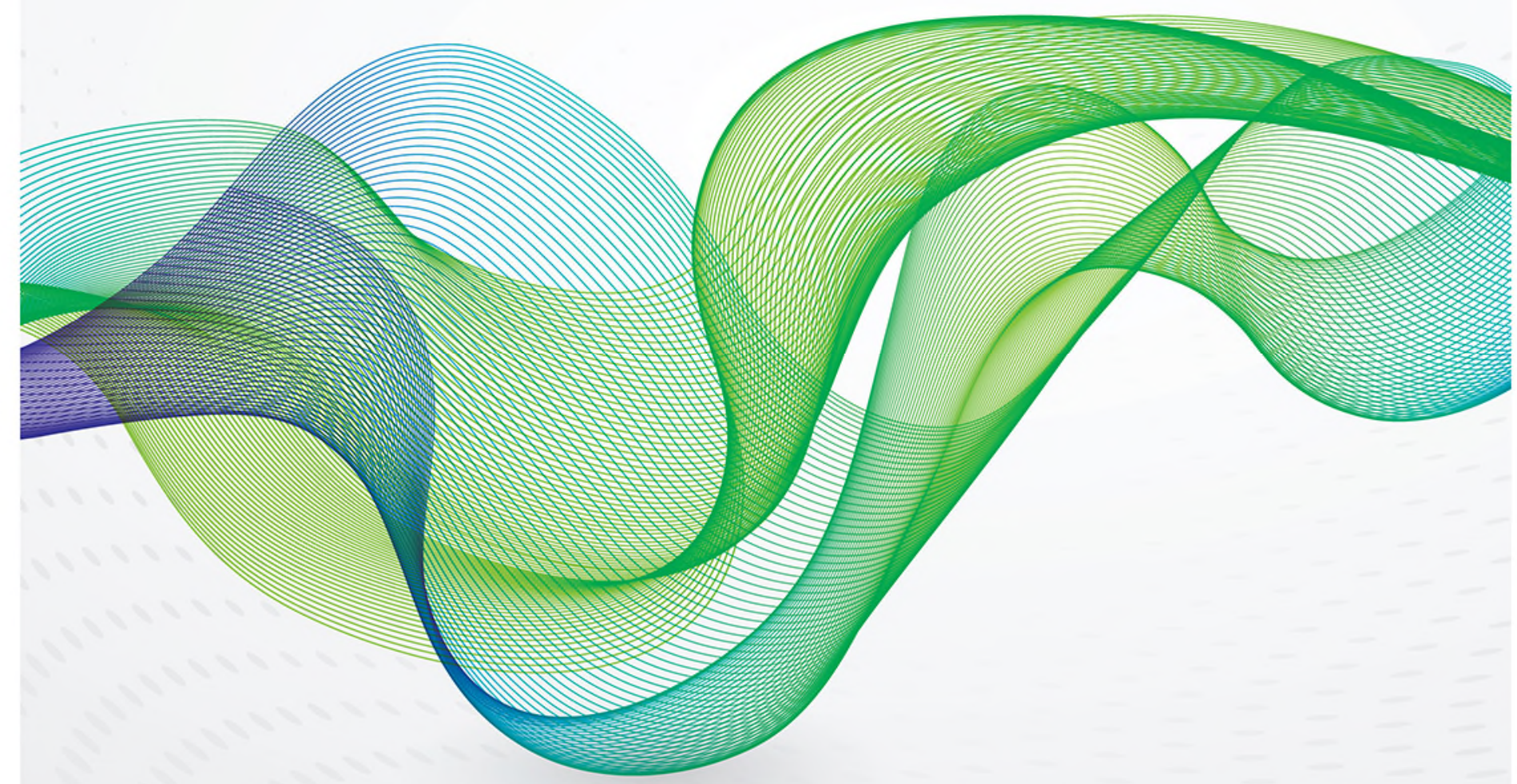



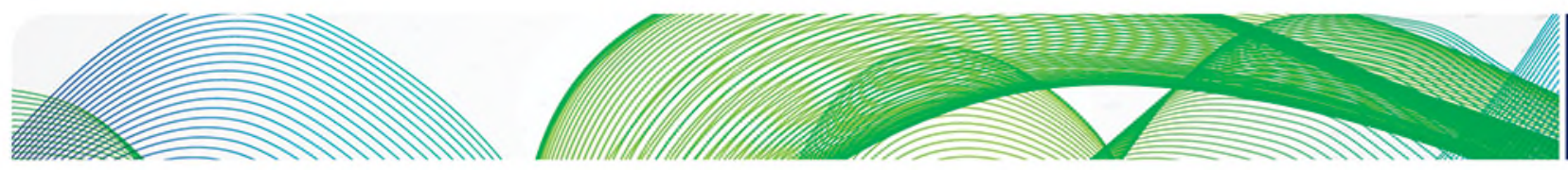

\section{애잔}

The contents of this paper are the author's sole responsibility. They do not necessarily represent the views of the Oxford Institute for Energy Studies or any of its members.

Copyright @ 2016

Oxford Institute for Energy Studies

(Registered Charity, No. 286084)

This publication may be reproduced in part for educational or non-profit purposes without special permission from the copyright holder, provided acknowledgment of the source is made. No use of this publication may be made for resale or for any other commercial purpose whatsoever without prior permission in writing from the Oxford Institute for Energy Studies.

ISBN 978-1-78467-067-2 

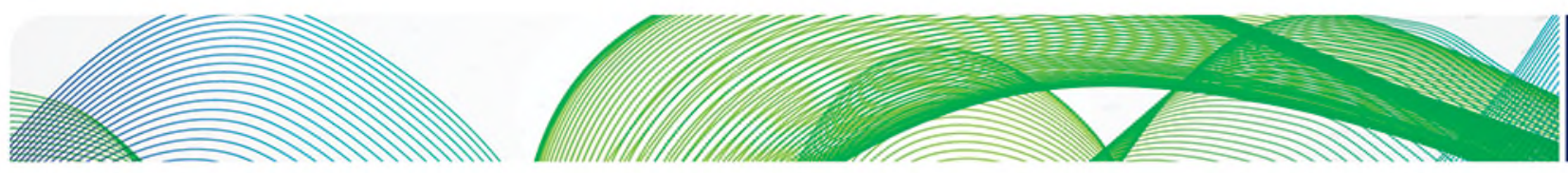

\section{O는}

\section{Acknowledgements}

The author is grateful to Bassam Fattouh, Laura El-Katiri, and Eliza Gheorghe for their invaluable comments on this paper and for their kind support and encouragement. He also thanks Kate Teasdale and Scott McLachlan for their assistance at the Institute.

OIES is grateful to the Kuwait Foundation for the Advancement of Sciences (KFAS) which facilitated this research. 

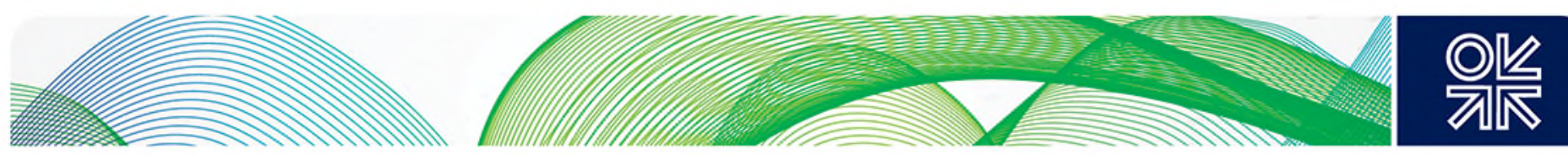

\section{Abbreviations}

ABWR: advanced boiling water reactor

ADWEA: Abu Dhabi Water and Electricity Authority

APWR: advanced pressurized water reactor

c-Si: crystalline silicon

CIS: copper, indium, selenide

CGN: China General Nuclear Power Group

CNNC: China National Nuclear Corporation

CSP: concentrated solar power

DEWA: Dubai Electricity and Water Authority

ENEC: Emirates Nuclear Energy Corporation

ENET: export-oriented nuclear energy technology

ENRET: export-oriented nuclear/renewable energy technology

EPC: engineering, procurement, construction

ERET: export-oriented renewable energy technology

FIT: feed-in tariff

GCC: Gulf Cooperation Council

GGGI: Global Green Growth Institute

IEA: International Energy Agency

IRENA: International Renewable Energy Agency

ISCC: integrated solar combined cycle

KAERI: Korea Atomic Energy Research Institute

KACARE: King Abdullah City for Atomic and Renewable Energy

KACST: King Abdulaziz City for Science and Technology

KEPCO: Korea Electric Power Corporation

KISR: Kuwait Institute for Scientific Research

MENA: Middle East and North Africa

MHI: Mitsubishi Heavy Industries

PHWR: pressurized heavy water reactor

PV: photovoltaics

PWR: pressurized water reactor

SEC: Saudi Electricity Company

SNPTC: State Nuclear Power Technology Corporation (China)

Unit

kW: kilowatt(s)

kWh: kilowatt hour

MW: megawatt(s)

GW: gigawatt(s) 

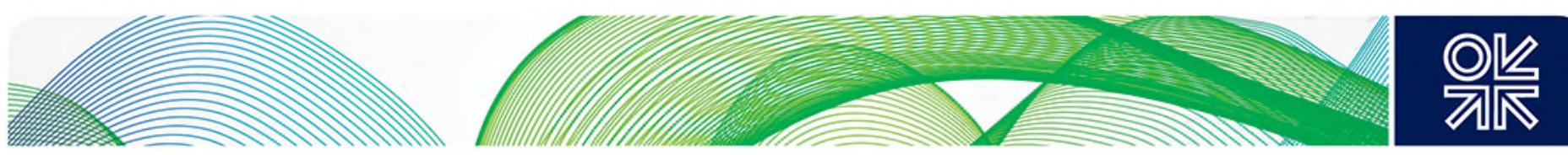

\section{Contents}

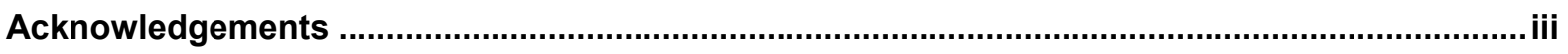

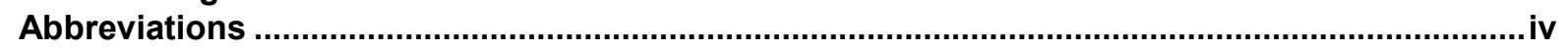

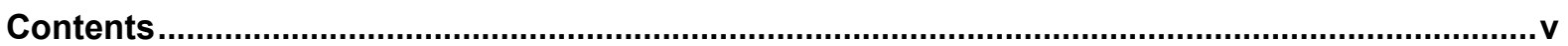

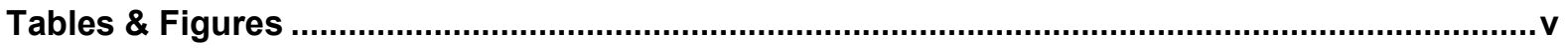

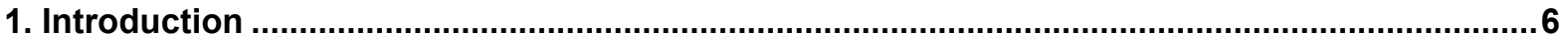

2. GCC-East Asia Relations in the Field of Nuclear Energy...................................................

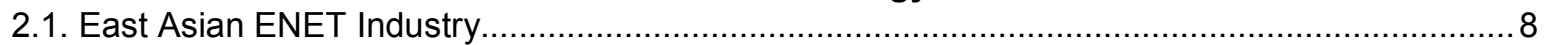

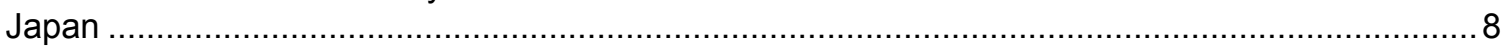

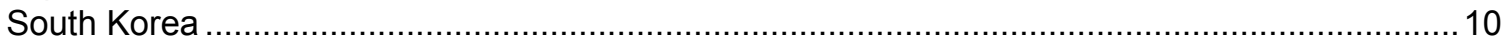

China

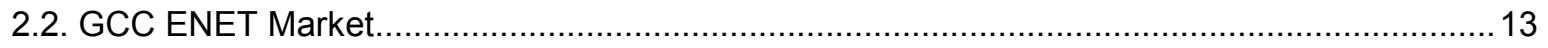

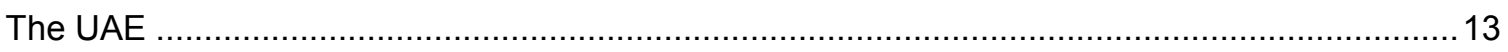

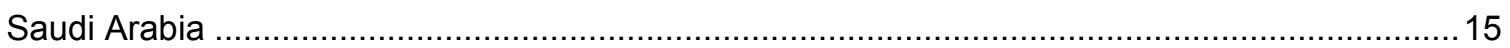

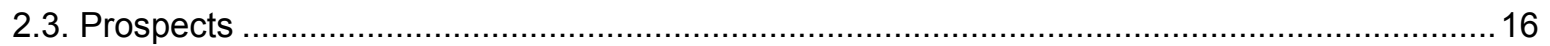

2.4. The Rise of Russia in the Global ENET Market............................................................. 17

3. GCC-East Asia Relations in the Field of Renewable (Solar) Energy .....................................18

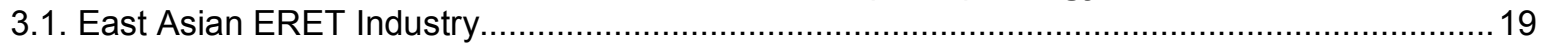

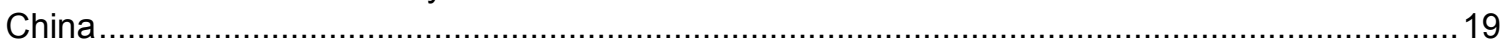

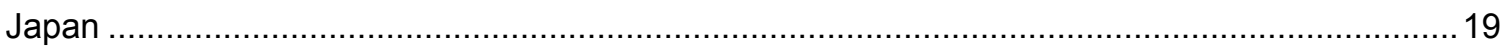

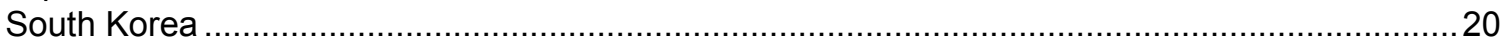

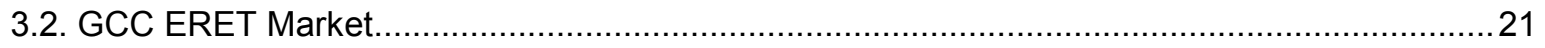

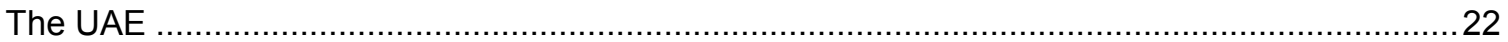

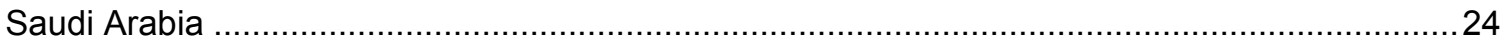

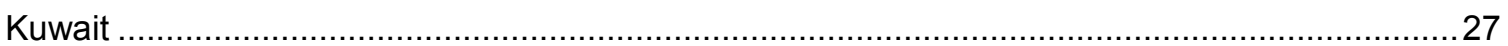

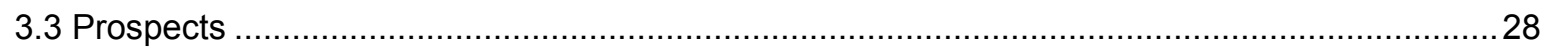

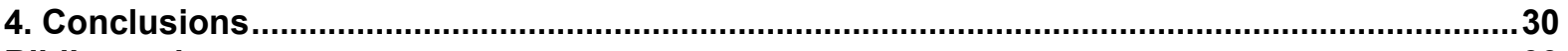

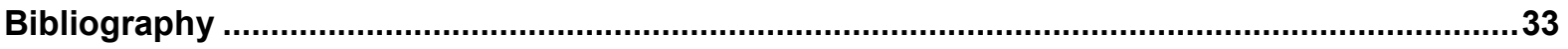

\section{Tables}

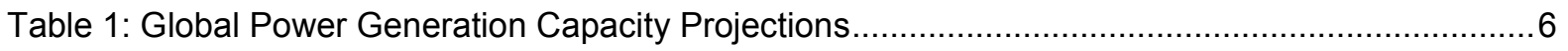

Table 2: The Top 10 Nuclear Energy Countries in the World (2015) ............................................. 8

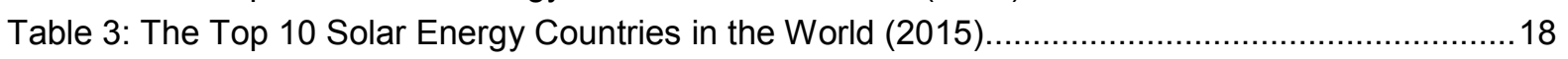

Table 4: GCC and Arab Countries' Installed Solar Power Capacity (Unit: MW)...............................21

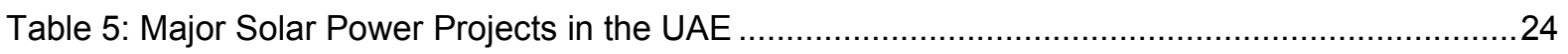

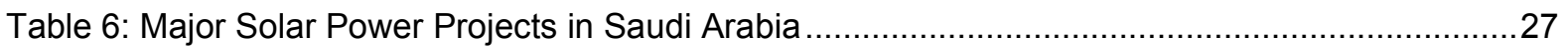

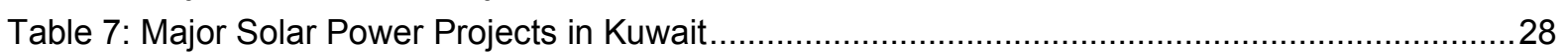



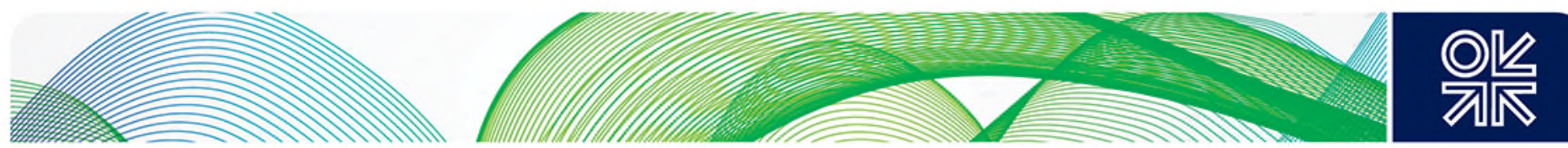

\section{Introduction}

GCC countries, which are the world's leading oil and gas-exporting countries, and East Asian countries, which are resource-scarce industrial powerhouses, have highly complementary relationships between them. The supply of oil and gas by GCC countries is integral to the energy security of East Asian states, while demand from East Asia for these hydrocarbon energy sources is crucial to the regime security of GCC states with a rentier fiscal structure. ${ }^{1}$ Although the current oil glut provides East Asian countries with greater opportunities to diversify the sources of their oil imports, the two regions will remain mutually indispensable to each other in the coming years.

Accordingly, there have been a number of studies focusing on the GCC-East Asia hydrocarbon energy nexus. However, new sources of energy - such as nuclear and solar - are being added to this nexus today. According to the latest report by the International Energy Agency (IEA), nuclear and solar energy, combined, accounted for 9.1 per cent of the global power generation capacity in 2013 (nuclear 6.7 per cent and solar 2.4 per cent). These sources of energy are expected to account for 11.7 per cent of the global power generation capacity by 2020 (nuclear 6.1 per cent and solar 5.6 per cent), and 13.0 per cent by 2025 (nuclear 5.9 per cent and solar 7.1 per cent). ${ }^{2}$

While some regions have entered the 'nuclear renaissance' and are also currently witnessing the rise of 'new sunbathers', a series of substantial and noteworthy developments regarding these nonhydrocarbon sources of energy have been occurring both in the GCC and East Asia. Nevertheless, partly because these developments are quite recent ones, there are few studies that examine GCCEast Asia relations in the fields of non-hydrocarbon energy. ${ }^{3}$

Table 1: Global Power Generation Capacity Projections

\begin{tabular}{|l|r|r|r|r|r|r|}
\hline \multirow{2}{*}{ Source } & \multicolumn{2}{c|}{$\mathbf{2 0 1 3}$} & \multicolumn{2}{c|}{$\mathbf{2 0 2 0}$} & \multicolumn{2}{c|}{$\mathbf{2 0 2 5}$} \\
\cline { 2 - 7 } & GW & \% & GW & \% & GW & $\%$ \\
\hline Coal & 1,851 & 31.5 & 2,064 & 28.3 & 2,164 & 26.7 \\
\hline Oil and Gas & 1,941 & 33.0 & 2,254 & 30.9 & 2,381 & 29.3 \\
\hline Hydro & 1,136 & 19.3 & 1,341 & 18.4 & 1,482 & 18.2 \\
\hline Nuclear & 392 & 6.7 & 448 & 6.1 & 482 & 5.9 \\
\hline Solar & 141 & 2.4 & 406 & 5.6 & 575 & 7.1 \\
\hline Others (e.g. Wind) & 423 & 7.2 & 786 & 10.8 & 1,050 & 12.9 \\
\hline \hline Total & 5,884 & 100.0 & 7,299 & 100.0 & 8,134 & 100.0 \\
\hline
\end{tabular}

Source: International Energy Agency

Until recently, the two regions had not been able to find cooperative relationships in the fields of nuclear and renewable energy. East Asian countries had begun investing in these non-hydrocarbon sources of energy following the Oil Crisis of 1973 in order to diversify their energy mix away from oil and enhance the level of their energy security. The GCC countries perceived such developments as a threat to their long-term fiscal security.

Nevertheless, dynamics have started to change in recent years. A game changer was the rise of domestic energy consumption in the GCC countries due to multiple factors such as population growth, rapid industrial diversification, and increasing water desalination. ${ }^{4} \mathrm{GCC}$ policy makers have begun to

\footnotetext{
Luciani 1987

2 International Energy Agency 2015: 586.

${ }^{3}$ See for instance, Calabrese 2015; Banerjee 2016.

${ }^{4}$ International Renewable Energy Agency 2016: 11.
} 

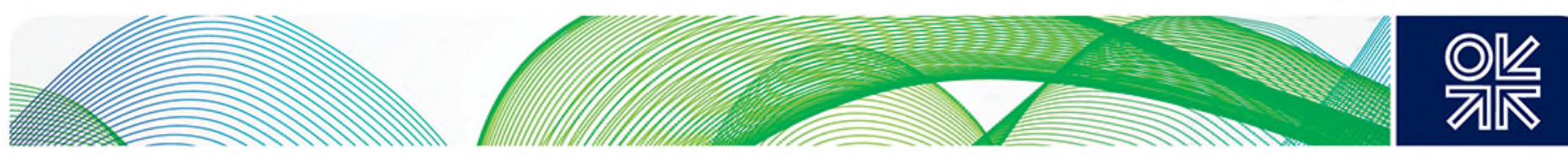

see the need to develop alternative energy sources in order to preserve the countries' capacity to export hydrocarbon energy sources in the coming decades. ${ }^{5}$ In the case of nuclear energy, its dualuse nature has also been inviting an interpretation that the GCC states, especially Saudi Arabia, aim to develop it as a balancing act against Iran's nuclear programme, and as a step towards becoming 'Iatent' nuclear powers - like Germany, Japan, Argentina, or Brazil - with a cadre of nuclear experts. ${ }^{6}$

Some fundamental questions about emerging GCC-East Asia relations in the fields of nuclear and renewable energy need to be answered.

- What patterns of relationships have been developing, and are likely to develop, in these fields?

- Can the two regions find complementary relationships between them, as they have done in the field of hydrocarbon energy?

- What opportunities exist for the two regions to develop cooperative ties between them in these fields, and what barriers to that development are anticipated?

This paper is one of the first attempts to delineate the contours of such a GCC-East Asia new energy nexus, which is expected to become one of the major pillars underpinning relations between these two regions in the coming decades. ${ }^{7}$ A new term, 'ENRET' (export-oriented nuclear/renewable energy technology) is suggested here, to identify the transfer of technology from East Asian countries to GCC countries as the main dynamic in forming relationships between the two regions in the fields of nuclear and renewable energy. On one hand, the GCC countries have been seeking technology from across the world to develop the foundation of their nuclear and renewable energy industries. East Asian countries, on the other hand, see their technological expertise in these fields as an exportable asset that can contribute to the sustainable growth of their economies.

\section{GCC-East Asia Relations in the Field of Nuclear Energy}

The GCC countries' civilian nuclear programmes can be contextualized within the global phenomenon called 'nuclear renaissance'. This nuclear renaissance has arrived following nearly two decades of 'winter' in the global nuclear industry, since the Chernobyl disaster in $1986 .^{8}$ According to one count, there were 81 new reactors under construction and 100 under planning in the world at the end of $2013 .{ }^{9}$ Over three-quarters of these were located in non-OECD countries; over half were in BRIC countries; and nearly a dozen countries (such as the UAE, Belarus, Turkey, Indonesia, Vietnam, Egypt, Bangladesh, Jordan, Kazakhstan, Poland, and Saudi Arabia) were either implementing or planning their first reactor. ${ }^{10}$ While the majority of these are oil/gas importing emerging economies which want to diversify their energy sources, they are also seeking nuclear power as a source of national pride and prestige, and as a symbol of their achievement of modernity. ${ }^{11}$

\footnotetext{
5 For the analyses of the dynamics behind the development of nuclear and renewable energy in the GCC countries, see Bahgat (2012, 2013, 2015), El-Katiri (2012, 2013), El-Katiri and Husain (2014), and Luomi (2012, 2015).

${ }^{6}$ Lippman 2012; Cigar 2016.

7 This study focuses on the links between three East Asian countries (China, Japan, and South Korea) and three GCC countries (Kuwait, the UAE, and Saudi Arabia).

${ }^{8}$ World Nuclear Association, 'The Nuclear Renaissance', September 2015.

9 中野 2015: 3.

${ }^{10}$ International Institute for Strategic Studies 2014; World Nuclear Association, 'Emerging Nuclear Energy Countries', February 2016

${ }^{11}$ Luomi 2012; Cigar 2016
} 

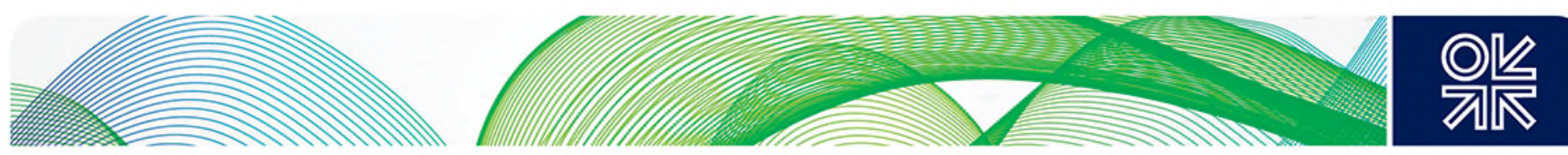

Table 2: The Top 10 Nuclear Energy Countries in the World (2015)

\begin{tabular}{|c|c|c||c|c|c|}
\hline No. & Country & Capacity & No. & Country & Capacity \\
\hline 1 & USA & $98.7 \mathrm{GW}$ & 6 & South Korea & $23.0 \mathrm{GW}$ \\
\hline 2 & France & $63.2 \mathrm{GW}$ & 7 & Ukraine & $13.8 \mathrm{GW}$ \\
\hline 3 & Japan & $(44.6 \mathrm{GW})$ & 8 & Canada & $13.5 \mathrm{GW}$ \\
\hline 4 & China & $26.0 \mathrm{GW}$ & 9 & Germany & $12.1 \mathrm{GW}$ \\
\hline 4 & Russia & $26.0 \mathrm{GW}$ & 10 & UK & $9.5 \mathrm{GW}$ \\
\hline
\end{tabular}

Source: World Nuclear Association

The global nuclear renaissance offers lucrative opportunities for East Asian ENET (export-oriented nuclear energy technology) producers. Having developed nuclear energy technology initially as a way of enhancing the level of energy security, East Asian policy makers also see the technology as an exportable industrial asset which will contribute to the sustainable growth of their economies. All three East Asian states (Japan, South Korea, and China) identify the export of nuclear reactors as a major pillar of their growth strategies, in spite of the different economic situations facing them.

For Japan, the export of value-added infrastructures is one of the new identities of its mature economy, which has already passed the stage of mass production of industrial products. In contrast, China is today a rising factory of the world, but, with over-billion citizens, the country's GDP per capita is still below the global average and Chinese policy makers see the necessity of searching out economic opportunities abroad (they call the policy zouquchu (走去出), or 'going out'). For South Korea, upgrading technology and exploring foreign markets have also been economic priorities due to the small size of its domestic market, the fact that its economy always struggles with being 'sandwiched' by high-tech Japan and cost-competitive China, and competition from another Tiger: Taiwan. Today, therefore, these three East Asian countries are all making great efforts to market their latest reactor designs around the world.

\subsection{East Asian ENET Industry}

Japan

Japan is one of the world's five established reactor-exporting countries. The country has three exportable third-generation reactor designs: ABWR, APWR, and Atmea-1. ${ }^{12}$ Reactors with these designs can be built by three Japanese firms: Toshiba (東芝), Hitachi (日立), and Mitsubishi Heavy Industries (MHI) (三菱重工). Japan's history of operating nuclear reactors is over half a century long. The country's first reactor, in Tokaimura (東海村), was connected to the grid in 1963. The construction of reactors accelerated in the aftermath of the Oil Crisis of 1973. Before 2011, Japan had 54 operating reactors providing nearly a third of the country's power supply. ${ }^{13}$

Japan's third-generation reactor designs were developed in cooperation with Western firms. In 1997, a consortium of Toshiba, Hitachi, and the USA's GE constructed the world's first third-generation reactors (two of them) in Kashiwazaki (柏崎), using the ABWR design. This was followed by the construction of two other ABWR reactors in Hamaoka (浜岡) and Shika (志賀). The APWR design was co-developed by MHI and the USA's Westinghouse, and the first two APWR reactors are under construction in Tsuruga (敦賀). The Atmea-1 design was co-developed by MHI and France's Areva; the first reactors using this design are likely to be built in Sinop, Turkey.

Japan's reactor-exporting policy was initially driven by the halting of its domestic nuclear market growth. After three decades of steady growth (since the early 1970s), Japan's nuclear power capacity hit a ceiling at around the turn of the century. In particular, the accident at the Tokaimura nuclear plant

\footnotetext{
${ }^{12}$ World Nuclear Association, 'Nuclear Power in Japan', March 2016

${ }^{13}$ Vivoda 2014
} 

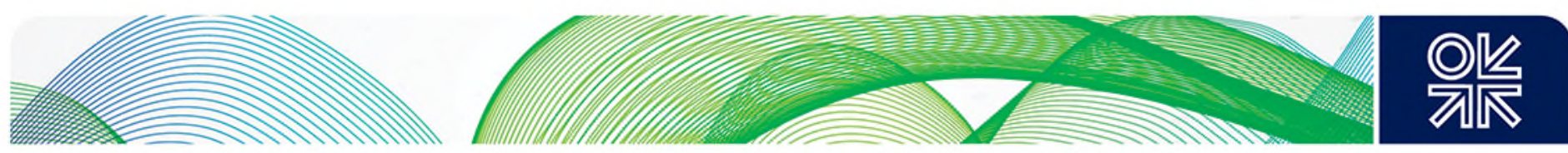

in September 1999, in which two workers at the plant were killed by radiation leaks, made Japanese citizens more sceptical about the safety of nuclear power. Although the majority of citizens still supported the use of nuclear power itself, the accident made it harder for the government to endorse plans for further expansion of the domestic nuclear industry. ${ }^{14}$ Therefore, Japanese nuclear firms inevitably had to begin seeking foreign markets, and that coincided with the harbinger of the global nuclear renaissance in the 2000s.

The Japanese firms mentioned above have found common interests with Western firms - forming alliances in order to reinforce their global marketing capacity in light of the rise of other reactorexporting players such as Russia's Rosatom, South Korea's KEPCO, and China's multiple stateowned enterprises. In 2006, Toshiba acquired the USA's Westinghouse. Likewise, in 2010, consortiums were formed between Hitachi and the USA's GE, and between MHI and France's Areva. ${ }^{15}$

These firms and consortiums also began receiving greater support from the Japanese government following KEPCO's winning of the UAE project in 2009, which Tokyo saw as an outcome of the South Korean government's full backing of the Korean company. In October 2010, the International Nuclear Energy Development of Japan (JINED) (国際原子力開発) was established as a centralized agency for activities related to Japan's export of reactors. JINED is a consortium of 13 Japanese firms: three reactor firms, nine regional utility companies, and the Innovation Network Corporation of Japan (INCJ) (産業革新機構), a public-private partnership which was created in 2009 to empower Japanese firms in innovation. ${ }^{16}$

The American and French governments also support Japan's global marketing efforts. Washington in particular (because of its intention to maintain its control over the global nuclear regime in light of the rise of Russia and China in the global ENET market), has supported Tokyo's continuation of its reactor-exporting policy since the Fukushima disaster, encouraging Japan to keep playing the role of 'responsible stakeholder' in nuclear non-proliferation. ${ }^{17}$

Japan's reactor-exporting policy continued in spite of the Fukushima disaster in 2011; in fact, the policy continued partly because of the Fukushima disaster, as the disaster had almost put an end to the possibility of further growth in the domestic nuclear market. ${ }^{18}$ Following the disaster, the Japanese government - led at that time by the Democratic Party of Japan (DPJ) (民主党) - halted the operation of the country's 50 remaining reactors and discussed their phasing out. ${ }^{19}$

Then the Liberal Democratic Party (LDP) (自由民主党), which had promoted the growth of the nuclear industry in the previous half century under its de facto one-party rule, returned to power at the end of 2012 and began re-embracing the use of nuclear power. Japan's Fourth Strategic Energy Plan (エネ ルギー基本計画), announced in April 2014, called for the restart of the halted nuclear reactors. Nevertheless, the plan, responding to public concern, stated that the share of nuclear in the country's energy mix would be lower than before. ${ }^{20}$

In 2012, Japan signed nuclear cooperation agreements with Vietnam and Jordan. Vietnam is planning four reactors; while the first two will be built by Russia's Rosatom, the following two have been offered to Japan (possibly the MHI-Areva consortium). ${ }^{21}$ In Jordan, the MHI-Areva consortium joined the

\footnotetext{
14 Midford 2014: 73-75.

15 中野 2015: 13-18.

6 'Japanese Nuclear Exports Consortium Launches', World Nuclear News, 26 October 2010.

Center for Strategic and International Studies 2013: 20.

18 '原発輸出 国内で新設難しく、海外に活路’, 日本経済新聞, 2 August 2015.

19 Umbach 2014; 'Nuclear Export Policy Misguided', The Japan Times, 11 November 2011.

20 資源エネルギー庁 2014: 19-22.

21 “Construction of First Vietnam Reactor “to Begin in 2020”', NucNet, 7 December 2015; “政府、三菱重・アレバ連合の原発推 奨 ベトナム向け輸出で, 日本経済新聞, 2 August 2015.
} 

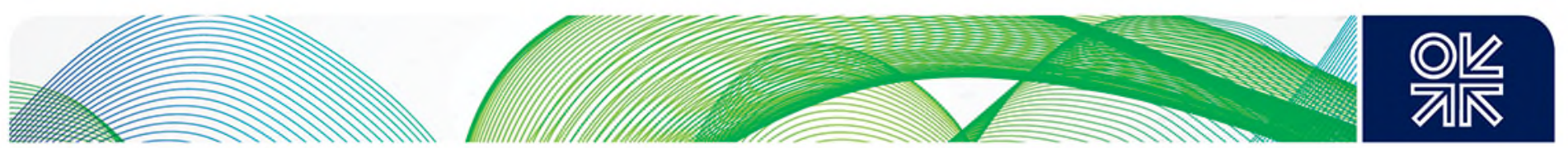

tender for the country's first two reactors, but the project was won by Rosatom. ${ }^{22}$ The major breakthrough for Japan came in May 2013 when it agreed with Turkey that the MHI-Areva consortium would build four reactors in Sinop, with the goal of launching the first reactor by 2023. The Sinop plant will be Turkey's second nuclear plant after the Akkuyu plant, where Rosatom will build four reactors. ${ }^{23}$ In December 2015, Japan also signed a nuclear accord with India. ${ }^{24}$

\section{South Korea}

South Korea is on the way to becoming the world's sixth reactor-exporting country with the UAE project currently being undertaken by the consortium led by Korea Electric Power Corporation (KEPCO) (한국전력공사), the country's semi state-owned utility company. South Korea's first reactor, in Kori (고리), was connected to the grid in 1977. Since then, the number of reactors in the country has increased to 24 , with a total capacity of $21 \mathrm{GW} .25$

The Second Basic Energy Plan (제 2 차에너지기본계획), disclosed in January 2014, set the target of more than doubling the country's nuclear capacity to $43 \mathrm{GW}$ by 2035 , which is equivalent to 29 per cent of its total power capacity. ${ }^{26}$ Previously, the target was the even more ambitious ' 41 per cent by 2030', but the downward revision was made in response to the rise of popular opposition to the use of nuclear power following Japan's Fukushima disaster and the revelation of large-scale corruption in the country's nuclear sector in 2013. ${ }^{27}$ Polling in 2015 showed that the majority of South Korea's citizens preferred maintaining the existing level of nuclear power, while only 30 per cent favoured more reactors. ${ }^{28}$

Among South Korea's existing 24 reactors, 14 were built using Western designs such as the PWR model provided by Westinghouse and France's Framatome (today's Areva) and the Canadian PHWR model. Absorbing technology from these Western firms, KEPCO and its subsidiary Korea Hydro and Nuclear Power (한국수력원자력) developed the country's indigenous design of second-generation reactors: OPR-1000. 10 reactors were built with the OPR-1000 design. Based on this success, KEPCO further developed its own third-generation reactor design, APR-1400, drawing on Westinghouse's CE System 80+ design. ${ }^{29}$

Construction of the country's first APR-1400 reactor (Shin Kori-3) began in 2008 and has already been completed; the reactor is currently awaiting its launch. The Shin Kori-3 reactor will serve as a prototype for the four APR-1400 reactors that KEPCO is currently building in the UAE. Before launching the UAE reactors, KEPCO is required to launch the commercial operation of the Shin Kori-3 reactor to prove the design's safety (see the following section on the UAE for details). In addition, three other APR-1400 reactors are under construction in South Korea: one in Kori (Shin Kori-4) and two in Ulchin (울진) (Shin Hanul-1 \& 2).

Although KEPCO's APR-1400 reactor is yet to prove its exportability, the company has been marketing the APR-1400 design globally. In November 2011, the South Korean government, led at that time by President Lee Myung-bak (이명박), revealed the plan called 'Nu-Tech 2030'; this aims to make South Korea the world's third-largest reactor-exporting country by 2030 , by achieving a 20 per cent share of the global nuclear market. ${ }^{30}$

Behind this plan was the fact that South Korea's economy needed to find new engines of growth and employment. Its economy had been relatively successful in the mid-2000s when the country was

\footnotetext{
22 World Nuclear Association, 'Nuclear Power in Jordan', May 2016.

${ }^{23}$ World Nuclear Association, 'Nuclear Power in Turkey', May 2016.

24 ‘日印原子力協定原発輸出、日本企業期待’, 毎日新聞, 12 December 2015.

${ }^{25}$ World Nuclear Association, 'Nuclear Power in South Korea', January 2016.

26 산업통상자원부 2014: 28.

27 'South Korea Cuts Target for Nuclear Power', The Financial Times, 14 January 2014.

${ }^{28}$ Dalton and Cha 2016

${ }^{29}$ World Nuclear Association, 'Nuclear Power in South Korea', January 2016.

30 'Seoul Seeks to Become World's Top 3 Nuclear Reactor Exporter', Yonhap News, 23 November 2011.
} 

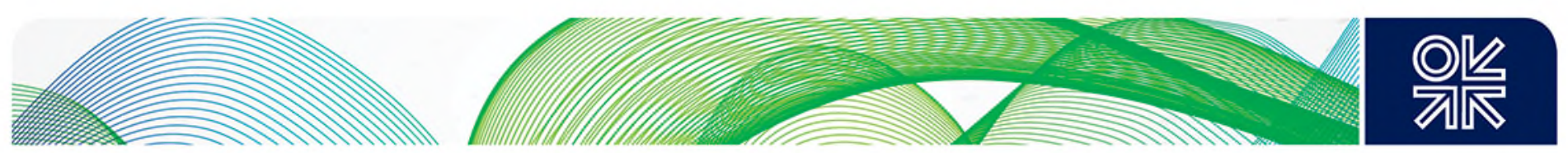

growing at rates over 5 per cent annually (owing to the effective technological upgrading of South Korean manufacturing firms). However, during the five years of the Lee administration (2008-13), which followed the global financial crisis, the country's average growth rate dipped to 3.2 per cent. ${ }^{31}$ As Japan's economy began recovering and Chinese manufacturing producers started to catch up in technological sectors, South Korea again began to suffer from its 'sandwiched' status. ${ }^{32}$

The Lee administration expected that KEPCO would repeat the success it had enjoyed in the UAE in other Middle Eastern markets, enabling it to capitalize on its early-mover advantage while Japan remained stigmatized with the memory of the Fukushima disaster and China was still in the middle of building up its technological capacity in the field of nuclear energy. Thus following the UAE deal in December 2009, South Korea launched negotiations with Turkey in March 2010 for reactors in Sinop.

The negotiations with Turkey, however, revealed South Korea's major weakness in this field: its limited financial capacity in comparison with its competitors. Discussions between KEPCO and its Turkish counterpart did not bear fruit because of their disagreement over methods of financing. While the costs of constructing reactors are expected to be recouped through the sale of electricity generated by the reactors once constructed, KEPCO's proposed electricity price and its request for electricity sales guarantees from the Turkish government were not accepted by Ankara, which wanted to keep the electricity price low. KEPCO found itself unable to borrow enough capital from its domestic financial market, given the conditions demanded by its Turkish counterpart. KEPCO finally withdrew from the negotiations in November 2010.33

In Jordan, the Korea Atomic Energy Research Institute (KAERI) (한국원자력연구원) and Daewoo Engineering \& Construction (대우건설) agreed in January 2010 to construct a research and training reactor for the Jordan University of Science and Technology (جامعة العلوم والتكنولوجيا الأردنية). The reactor in Irbid (اربد) is expected to be launched in, or before, August 2016. ${ }^{34}$ KEPCO expected that this project would be a stepping stone towards commercial nuclear power plant projects in Jordan. Nevertheless, KEPCO and the Jordanian government reportedly failed to make progress in negotiations, as KEPCO was unable to accept Amman's request to finance all the necessary investment for the project. ${ }^{35}$

\section{China}

China is not yet a reactor-exporting country, but it has been investing extensively in the development of the country's indigenous third-generation reactor designs. China's first reactor, in Qinshan (秦山) in Zhejiang Province (浙江省), was connected to the grid in 1991. Since then, China has built 30 reactors with a total capacity of $28 \mathrm{GW} .{ }^{36}$ Although the growth of its nuclear power capacity has slowed down temporarily in recent years, due to the Chinese government's more cautious attitude towards the safety of reactors since Japan's Fukushima disaster, ${ }^{37}$ the Chinese government has maintained its plan to more than double the current capacity and achieve a capacity of $58 \mathrm{GW}$ by 2020. ${ }^{38}$

Because of its relatively short history in the development of nuclear power, China's nuclear industry still largely remains at the stage of absorbing advanced foreign technology. Nevertheless, the Chinese government has also been keen on making the country a reactor-exporting country. Its Energy Development Strategy Action Plan (能源发展战略行动计划), announced in November 2014, identifies the export of reactors as being in line with China's zouquchu or 'going out' policy which encourages Chinese firms' greater commercial activities in foreign markets. ${ }^{39}$

\footnotetext{
${ }^{31}$ World Bank, World Data Bank, World Development Indicators.

32 “寿命を迎えた韓国型成長モデル 低迷する韓国経済’, 朝鮮日報, 30 December 2015 ,

33 中野 2015: 61; World Nuclear Association, 'Nuclear Power in Turkey’, May 2016.

34 'Export of Reactor: Jordan Research, Training Reactor to be Put into Operation Soon', Business Korea, 12 April 2016.

${ }^{35}$ Baklitsky 2013: 29

${ }^{36}$ World Nuclear Association, 'Nuclear Power in China', 23 February 2016.

37 'China Seeks United Front in Reactor Export Push', The Financial Times, 27 April 2015.

38 'China Unveils Energy Strategy, Targets for 2020', Xinhua, 19 November 2014.

39 国务院办公厅 2014.
} 

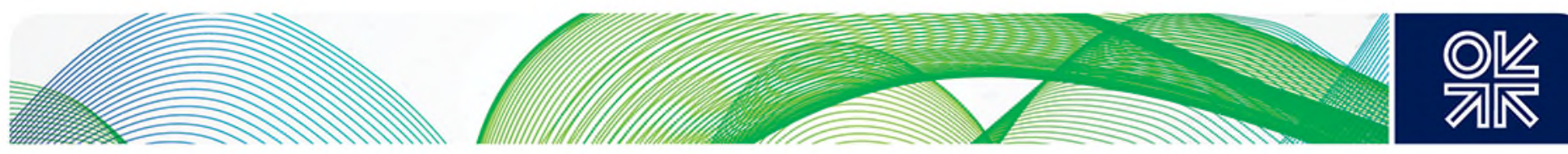

The policy, originally pursued by the previous Hu Jintao (胡锦涛) regime (2002-12) as a way of balancing China's conventional policy of attracting large volumes of FDI (yinjinlai or 'bringing in'), has recently been repackaged by the current Xi Jinping (习近平) regime (2012-present) into the One Belt One Road (一带一路) initiative; this envisions the twenty-first century version of the Silk Road. The export of nuclear reactors has been designated as one of the pillars of the initiative. In March 2016, Beijing disclosed its vision to export 30 reactors by $2030 .{ }^{40}$ For this purpose, reactors with two indigenous third-generation designs are currently under construction in China: CAP1400 and Hualong-1.

The CAP1400 design was developed by State Nuclear Power Technology Corporation (SNPTC) (国家 核电技术), a state-owned enterprise headquartered in the capital city, Beijing. SNPTC was created in 2007 for the specific purpose of absorbing third-generation reactor technology from foreign firms. The USA's Westinghouse (now owned by Toshiba) was selected by the Chinese government to be a technological partner for SNPTC. Four reactors using Westinghouse's AP1000 third-generation designs are currently under construction in China: two in Sanmen (三门) in Zhejiang Province and two others in Haiyang (海阳) in Shandong Province (山东省). ${ }^{41}$

Based on this AP1000 design, SNPTC developed China's indigenous CAP1400 design in cooperation with Westinghouse. Even before the launch of the AP1000 reactors, the Chinese government hastily approved the construction of the first CAP1400 reactor, which will serve as a prototype reactor to prove the design's safety and exportability. Construction of the reactor, in Shidaowan (石岛湾) in Shandong Province, began in December 2012.42 The initial plan was to connect the reactor to the grid by 2017 . However, construction has been delayed for undisclosed reasons. Now it is estimated that the launch of the reactor will only happen by the end of 2020.43

Meanwhile, the Chinese government began prioritizing the development of another third-generation design: Hualong-1 (华龙一号). ${ }^{44}$ (Hualong means 'Chinese dragon'.) Hualong-1 was jointly developed by the two rival Chinese state-owned enterprises that have been operating the country's existing reactors: China National Nuclear Corporation (CNNC) (中国核工业集团) based in Beijing, and China General Nuclear Power Group (CGN) (中国广核集团) headquartered in Shenzhen (深圳) in Guangdong Province (广东省). The Hualong-1 design was created by merging two different second-generation models: CNNC's ACP1000 design and CGN's CPR1000 design. ${ }^{45}$ Construction of the prototype Hualong-1 reactor, by CNNC in Fuqian (福清) in Fujian Province (福建省), began in May 2015.

Although this reactor will only come on stream in 2019 at the earliest, ${ }^{46}$ CNNC and CGN have already begun marketing Hualong-1 globally. In November 2015, CNNC agreed with Argentina that it will build two Hualong-1 reactors in Atucha. ${ }^{47}$ The company has also switched the design of two reactors it had previously agreed with Pakistan to construct in Karachi to Hualong-1 from the initially agreed ACP1000. ${ }^{48}$ Meanwhile, CGN has been seeking the construction of a 'UK version of Hualong-1 reactor' at Hinkley Point in the UK, through its investment in the project owned by France's EDF Energy. ${ }^{49}$ However, the project is currently under review by the new UK government led by PM Theresa May who assumed office in July 2016. ${ }^{50}$ In March 2016 CNNC and CGN eventually came

\footnotetext{
40 'China Plans 30 Overseas Nuclear Power Units by 2030', Xinhua, 1 March 2016.

${ }^{41}$ World Nuclear Association, 'Nuclear Power in China', 23 February 2016.

42 ‘核电重启: 华能石岛湾或成行业风向标’, 新华网, 15 December 2014.

${ }^{43}$ World Nuclear Association, 'Nuclear Power in China', 23 February 2016.

44 'China Seeks United Front in Reactor Export Push', The Financial Times, 27 April 2015.

45 'China's New Nuclear Baby', World Nuclear News, 2 September 2014.

${ }^{46}$ World Nuclear Association, 'Nuclear Power in China', 23 February 2016.

47 'Argentina and China Sign Two Reactor Construction Agreements', World Nuclear News, 16 November 2015.

48 'Pakistan Breaks Ground for New Karachi Units', World Nuclear News, 21 August 2015.

49 'China Agrees to Invest in New UK Nuclear Plant', World Nuclear News, 21 October 2015.

50 'Nuclear Power: When the Facts Change...', The Economist, 6 August 2016.
} 

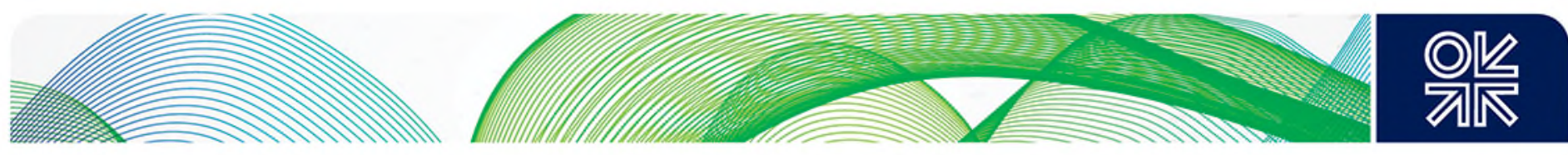

together to launch an equally-owned joint venture, Hualong International Nuclear Power Technology Corporation (华龙国际核电技术), to create a united front in marketing..$^{51}$

On the other hand, SNPTC has been separately marketing its CAP1400 design globally. In November 2014, SNPTC and Westinghouse launched negotiations for Turkey's third nuclear plant (following Akkuyu and Sinop).52 Previously, CGN had joined the bidding for the Sinop plant in 2013 and the company reportedly offered advantageous terms to Turkey (including full financing of the project) before the Japanese-French consortium won the deal. Some observe that although Turkey did not see CGN as a strong bidder, it used its talks with the company as a ploy to put pressure on other bidders. ${ }^{53}$

\subsection{GCC ENET Market}

In December 2016, the GCC announced that it was considering the setting up of a shared nuclear energy programme. Its member states then began independently studying and planning the use of nuclear power. Currently, the GCC's first nuclear reactors are under construction (by a South Korean consortium) in the UAE, with the first reactor expected to come on stream in 2017. Saudi Arabia is conducting two feasibility studies with South Korea and France to set up nuclear plants. Qatar and Oman have also been studying the use of nuclear power, but so far they have not found a strong case favouring the development of nuclear energy to meet their domestic power needs.

On the other hand, Kuwait has already abandoned its nuclear programme. Kuwait started planning to use nuclear energy in 2009 by setting up the National Nuclear Energy Committee (KNNEC) (اللجنة (الوطنية لاستخدامات الطاقة النووية). In 2010, the country signed nuclear cooperation agreements with the USA, Japan, France, and Russia, and announced its plan to build four $1 \mathrm{GW}$ reactors by 2022. Nevertheless, the plan was abandoned in 2011 following Japan's Fukushima disaster and the KNNEC was dissolved. ${ }^{54}$

\section{The UAE}

The UAE announced its nuclear energy development policy in 2008. Following this, in 2009 it created a regulatory institution and a state-owned enterprise for the nuclear industry: the Federal Authority for Nuclear Regulation (FANR) (الهيئة الاتحادية للرقابة النووية) and the Emirates Nuclear Energy Corporation (ENEC) (مؤسسة الإمارات للطاقة النووية) In December 2009, ENEC selected the consortium led by KEPCO as a developer of the country's first nuclear plant, in Barakah (براكة) in Abu Dhabi.

The plant will host four APR-1400 reactors, whose total capacity will be $5.6 \mathrm{GW}$, or nearly a quarter of the country's current power requirement. Construction of the first reactor began in July 2012 with the goal of being connected to the grid by May 2017. All four reactors are expected to be launched by 2020. The consortium includes Westinghouse, and its owner Toshiba, which provided the base design for KEPCO's APR-1400 reactor. ${ }^{56}$

The UAE's choice of KEPCO, which had no previous experience of exporting reactors, was received by the global nuclear industry with surprise. The decision impressed upon existing reactor-exporting countries the realization that an ever more intense competition in the industry was beginning. ${ }^{57}$ In fact, this achievement was the outcome of the South Korean government's strong political backing of KEPCO.

Before the agreement, Seoul's active diplomacy towards Abu Dhabi was undertaken by President Lee, who described his policy as the one that would create the 'second Middle East boom'

\footnotetext{
51 'Hualong One Joint Venture Officially Launched', World Nuclear News, 17 March 2016.

52 'Tripartite Agreement on Third Turkish Plant', World Nuclear News, 24 November 2014.

53 Baklitsky 2013: 29.

${ }^{54}$ World Nuclear Association, 'Emerging Nuclear Energy Countries', June 2016.

55 Bahgat 2012: 270-1.

56 'UAE Picks Korea as Nuclear Partner', World Nuclear News, 29 December 2009.

57 'Atomic Dawn', The Economist, 30 December 2009.
} 

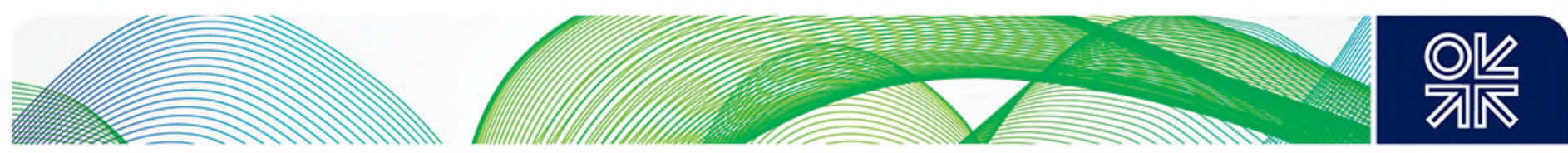

(제 2 의중동붐) for South Korea's economy. Lee, who was a CEO and chairman of Hyundai Construction (현대건설), an affiliate of one of the chaebols (a type of South Korean business conglomerate) before starting his political career, was proud of himself for creating the first such boom in the 1970s and the 1980s, when his company undertook a number of construction projects in the Gulf region under the first oil boom. ${ }^{58}$ Now as president, Lee returned to the region under the new oil bonanza, to market the country's value-added infrastructures.

Supported by the government, KEPCO offered the UAE exceptionally generous conditions in order to compensate its weakness as an inexperienced newcomer in the industry. These conditions included a price that was nearly 40 per cent cheaper than that of its competitors and the guarantee that the reactors would operate for 60 years. The latter means that KEPCO will have to undertake large maintenance and repairing costs in the future. ${ }^{59}$ In addition, a bilateral military cooperation agreement was signed at the same time between South Korea and the UAE; as a result of this, a special military unit from the South Korean army began to be dispatched in January 2011 to Al-Ain (العين) in Abu Dhabi, to train its counterpart in the UAE army. ${ }^{60}$

Furthermore, it was revealed more than a year later that nearly half of the construction costs for the project will be financed by loans from the Export-Import Bank of South Korea (한국수출입은행). This led to rising criticism in South Korea of the Lee administration, questioning the economic rationality of the project. Critics denounced the conditions of the agreement, which they deemed as being overly favourable to the UAE. Others considered (and demanded) that such an extraordinary deal would be a one-off and will not be repeated in other negotiations. ${ }^{61}$

South Korea also agreed with the UAE to offer training to Emirati workers in the nuclear industry. Anticipating the rise of the nuclear industry in the UAE, higher education institutions in the UAE such as the Institute of Applied Technology (معهد التكنولوجيا التطبيقية) and the Khalifa University for Science, Technology, and Research (جامعة خليفة للعلوم و التكنولوجيا و البحوث), have begun offering courses on nuclear technology. KEPCO has accepted students from these institutions for on-the-job training at nuclear sites in South Korea. ${ }^{62}$

As mentioned in the above section on South Korea, the agreement was made while KEPCO's prototype APR-1400 reactor in Kori was still under construction. KEPCO initially planned to launch this reactor to prove its safety to ENEC by the end of 2013. Nevertheless, the launch of the reactor kept being delayed due to a series of accidents - such as the incident involving falsification of documents relating to the cable used in the reactor in April 2013, and a gas leak that killed three workers in November 2014.63 (The cable incident, nonetheless, opened the supply of cables for South Korea's reactors to international manufacturers. Dubai's Ducab now supplies cables to reactors in South Korea, as well as to the Barakah reactors. $)^{64}$

KEPCO eventually failed to meet the agreed deadline of September 2015 for launching the reactor, and began to pay financial penalties of 500 million won (US\$420,000) monthly to ENEC. ${ }^{65}$ The reactor was eventually connected to the grid in January 2016. It was expected that the reactor would begin commercial operation in May, ${ }^{66}$ but as of the end of August this had not yet taken place. The delay in the launch of the prototype reactor, together with KEPCO's inability to secure further agreements

\footnotetext{
58 'Lee Myung-bak Calls for Second Middle East Boom', Chosun I/bo, 11 April 2007

59 中野 2015: 61-62

60 'South Korean Elite Forces Arrive in UAE', The National, 13 January 2011.

61 'Nuclear Power Plant Exports Boost Korea Inc.', The Korea Times, 21 February 2011.

62 'South Korea Trains UAE Students on Nuclear Plants', Emirates 24|7, 25 August 2010.

63 'UAE Nuclear Project Enters Critical Phase', The National, 7 July 2015.

64 'Ducab Wins Breakthrough Cabling Deal for South Korean Nuclear Reactors', The National, 18 May 2016.

65 ‘한국형 원전 신고리 3 호기 시운전, 최소 7 개월 지연 불가피...UAE 에 지불할 위약금 40 억원 “훌쩍”, , 경향신문, 7 September 2015.

66 'Grid Connection for First Korean APR-1400', World Nuclear News, 19 January 2016.
} 

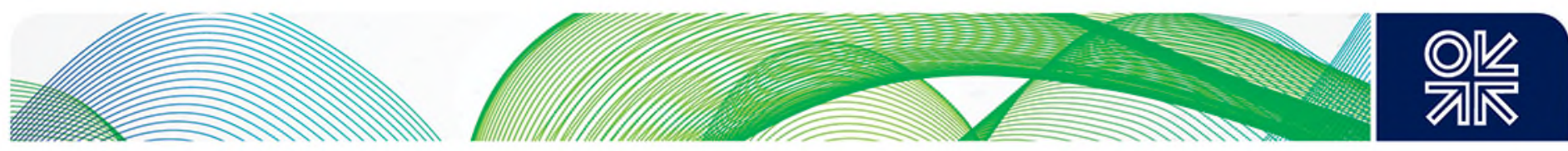

during the more than six years following the UAE deal in 2009 , have resulted in the rise of pessimism among South Korean citizens about the future of the country's ENET industry. ${ }^{67}$

At this point, the UAE has announced no concrete plans to build further reactors since the first four at the Barakah plant. However, Japan, which lost the bid against South Korea in 2009, has been seeking an opportunity to undertake projects in the UAE in the future. In May 2013 (the same month as its agreement with Turkey on the Sinop project), Japan signed a nuclear cooperation agreement with the UAE. ${ }^{68}$ The UAE has so far also signed nuclear cooperation agreements with other reactorexporting countries such as the USA, France, Russia, and Canada. ${ }^{69}$

\section{Saudi Arabia}

Saudi Arabia began seeking the development of nuclear and renewable energy by creating the King Abdullah City for Atomic and Renewable Energy (KACARE) (مدينة الملك عبد اله للطاقة الذرية والمتجدة) in April 2010. KACARE aims to produce $18 \mathrm{GW}$ through nuclear by $2032 .{ }^{70}$ To achieve this target, in June 2011 Saudi Arabia announced plans to build 16 nuclear reactors by 2030, with the first two coming online in 2022; two reactors would then be added every year. ${ }^{71}$ (In January 2015 , the final target year was pushed back to $2040 .{ }^{72}$ )

Prior to this, Saudi Arabia had signed a nuclear cooperation agreement with France in February 2011. In accordance with this agreement, Areva and EDF Energy agreed in July 2013 to provide training to Saudi nuclear industry workers. In June 2015, Saudi Arabia and France further agreed to carry out a feasibility study for constructing two EPR reactors. ${ }^{73}$ The EPR (or European pressurized water reactor) is an advanced third-generation (Generation III+) reactor developed by Areva. EPR reactors are currently built in Finland, France, and China. ${ }^{74}$

In March 2015, Saudi Arabia made an agreement with South Korea to implement a three-year feasibility study on building reactors. (South Korea had initially launched talks with Saudi Arabia on nuclear cooperation in November 2011.) This agreement took the form of a memorandum of understanding, and it was signed between KACARE and KAERI for cooperation on the $330 \mathrm{MW}$ reactor known as SMART ('system-integrated modular advanced reactor'). This is a small-sized fourth-generation pressurized water reactor developed by KAERI.

KAERI and KACARE agreed on the transfer of nuclear technology and on human capital development in the Saudi nuclear industry, as well as the joint promotion of the SMART reactor globally. ${ }^{75} \mathrm{KAERI}$ initially planned to launch a $90 \mathrm{MW}$ demonstration SMART reactor in South Korea in 2017,76 but construction of the reactor has not yet begun: a media report in South Korea in May 2016 suggested that the project had been delayed since the beginning of the year due to a confrontation between the auditor and the management and the labour union of KAERI. ${ }^{77}$

China also signed a nuclear cooperation agreement with Saudi Arabia, in January 2012. Following this, in August 2014 KACARE and CNNC, a co-developer of Hualong-1, signed a memorandum of understanding to promote cooperation. ${ }^{78}$ Nevertheless, in January 2016, at the time of President Xi Jinping's visit to Riyadh, China Nuclear Engineering Corporation (CNEC) (中国核工业建设集团公司), a

\footnotetext{
67 ‘韓経：【コラム】大統領がセールス外交に出ると言うが...., 中央日報, 28 January 2016.

68 'UAE, Japan Sign up for Nuclear Cooperation', World Nuclear News, 2 May 2013.

${ }^{69}$ World Nuclear Association, 'Nuclear Power in the United Arab Emirates', April 2016.

70 'Saudi Arabia Aims to be World's Largest Renewable Energy Market', Arab News, 18 July 2013.

'Saudi Plans to Build 16 Nuclear Reactors by 2030', Reuters, 1 June 2011.

72 'Saudi Arabia's Nuclear, Renewable Energy Plans Pushed Back', Reuters, 19 January 2015.

73 'France to Study Reactor Construction in Saudi Arabia', World Nuclear News, 26 June 2015.

${ }^{74}$ World Nuclear Association, 'Advanced Nuclear Power Reactors', May 2016.

75 'Saudi Arabia and Korea Further SMART Cooperation', World Nuclear News, 3 September 2015

${ }^{76}$ World Nuclear Association, 'Nuclear Power in South Korea', June 2016.

77 ‘순항하던 SMART “암초에 부딪치다”', 원자력신문, 10 May 2016.

${ }^{78}$ World Nuclear Association, 'Nuclear Power in Saudi Arabia', January 2016.
} 

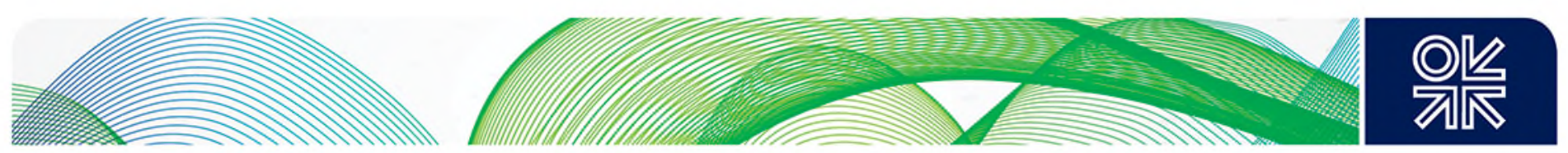

different state-owned enterprise headquartered in Beijing, signed another agreement with KACARE to cooperate on the HTR reactor. ${ }^{79}$

The HTR (or high-temperature gas-cooled reactor) is a small-sized fourth-generation reactor designed by CNEC, which developed this design in cooperation with Tsinghua University (清华大学). The construction of a $200 \mathrm{MW}$ demonstration HTR reactor in Shidaowan began in 2012, with the goal of being connected to the grid by 2017. CNEC is also planning to start building two $600 \mathrm{MW}$ commercial HTR reactors in Ruijin (瑞金) in Jiangxi Province (江西省) in 2017, with the goal of launching their operation by 2021.80

In June 2015, Saudi Arabia also signed a nuclear cooperation deal with Russia's Rosatom ${ }^{81}$ It has also been involved in technological cooperation with Argentina, to develop a small-sized reactor for use in desalination. In addition, Japan has been in talks with Saudi Arabia regarding nuclear cooperation since February 2013. ${ }^{82}$

As the above developments show, Saudi Arabia is interested in hosting reactors with the latest designs. Nevertheless, it is likely that the global deployment of fourth-generation reactors will come only after 2020. ${ }^{83}$ This suggests that Saudi Arabia may now be considering the development of nuclear power as a long-term project. Its National Transformation Programme 2020 (برنامج التحول الوطني ? 2020), disclosed in June 2016, only set the goal for KACARE to '[i]dentify and prepare the construction locations of the first nuclear power plant sites and provide necessary infrastructure' and 'develop needed qualitative human capabilities'. ${ }^{84}$ This hints that construction of the country's first reactors will begin after 2020, and their commercial operation will probably take place after 2025.

\subsection{Prospects}

By 2020, the UAE is expected to host its first four reactors; Saudi Arabia may possibly also host some initial reactors by 2025 , while the UAE may host additional ones. The three East Asian countries have all been making great efforts to market their reactor designs in the GCC and MENA countries, as well as in other parts of the world. Nevertheless, as the above analysis shows, each country's capacity to export its reactors varies.

South Korea is set to become a new reactor-exporting country with KEPCO's current project in the UAE. Seoul, with its ambitious 'Nu-Tech 2030' vision (aiming to occupy one-fifth of the global ENET market by 2030) had expected that the UAE project would be a bridgehead for KEPCO's rise as a major global reactor-exporter. However, as mentioned above, the company has been struggling with the launch of its prototype APR-1400 reactor in Kori, which has been delayed for two and half years since the initially planned date. South Korea is conducting a feasibility study to set up reactors in Saudi Arabia as well, but this project has also been experiencing a delay at its initial stage. Ultimately, whether KEPCO can successfully launch the first Barakah reactor by 2017 , as scheduled, following the launch of the prototype Kori reactor, will substantially affect its credibility as a newcomer in this industry.

China is not yet a reactor-exporting country. It is currently constructing prototype reactors with indigenous third-generation designs: CAP1400 developed by SNPTC, and Hualong-1 co-developed by CNNC and CGN. Although it will take at least several more years before these reactors can be launched to prove their exportability Beijing, following Seoul's strategy, has already made a few international agreements on their export. Chinese firms have also been in talks with Saudi Arabia, but

\footnotetext{
79 'China, Saudi Arabia Agree to Build HTR', World Nuclear News, 20 January 2016.

80 World Nuclear Association, 'Nuclear Power in China', April 2016.

81 'Russia and Saudi Arabia Agree to Cooperate in Nuclear Energy', World Nuclear News, 19 June 2015.

82 'Tokyo Offers Riyadh Nuclear Power Help', Arab News, 11 February 2013.

${ }^{83}$ World Nuclear Association, 'Generation IV Nuclear Reactors', August 2015.

84 The Kingdom of Saudi Arabia 2016: 109.
} 

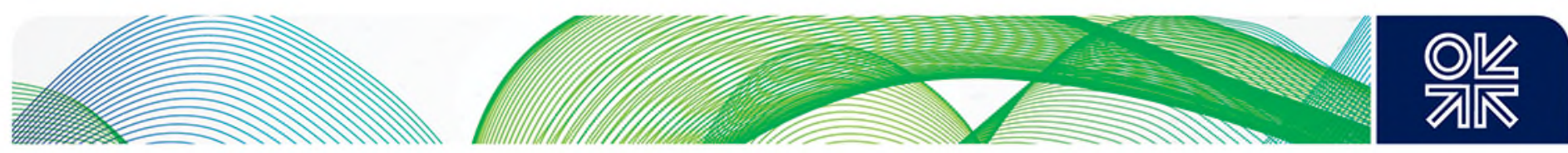

Riyadh may watch how their agreed projects in other countries, such as Argentina and Pakistan, unfold before concluding agreements.

Japan already has a reactor-exporting capacity. With the low likelihood of re-growth of its domestic nuclear market after Fukushima, Japanese firms have also been proactively exploring foreign markets. Having won the deal in Turkey in 2013, they keep seeking opportunities in the GCC and MENA countries. Because of their alliances with American and French firms, Japanese firms are supported by Washington and Paris, as well as their own government, in their global marketing. The USA is especially keen on maintaining its influence on the global nuclear regime in relation to nonproliferation, in light of the rise of Russia and China in the global ENET market.

Nevertheless, this can also impose a constraint on Japanese firms, if a host state wants to remain free from the influence of the world's hegemonic power in its own nuclear sphere. For Japanese-US consortiums to win a contract, both Tokyo and Washington need to sign a bilateral nuclear cooperation agreement with the host state in advance. This means that the agreement must be approved by the US Congress. Currently, the US Congress is only likely to approve the agreement (which is called a 123 Agreement in reference to Section 123 of the US Atomic Energy Act of 1954) when the host state makes a commitment not to develop an independent nuclear fuel cycle, which is a prerequisite for the weaponization of nuclear materials. So far, the UAE - as well as Egypt and Turkey - has signed the agreement with the USA, but Saudi Arabia has not. ${ }^{85}$

\subsection{The Rise of Russia in the Global ENET Market}

Finally, the above analysis suggests that intensification of competition between reactor-exporters is to be expected. Such competition is likely to take place both between East Asian exporters and with others. ${ }^{86}$ In particular, Rosatom, Russia's state-owned enterprise, has been making rapid inroads into the global ENET market in recent years.

Russia is home to 34 operating reactors with a total capacity of $25 \mathrm{GW}$. The country has developed three indigenous third-generation reactor designs: VVER-1000, VVER-1200, and VVER-TOI. Since its creation in 2007, Rosatom has been aggressively marketing these reactors globally. At the end of 2015, five Russian reactors were under construction in three countries (China, India, and Belarus); 14 had been contracted in seven countries (India, Bangladesh, Vietnam, Iran, Turkey, Armenia, and Finland); and 15 had been ordered in seven countries (China, India, Vietnam, Egypt, Jordan, Hungary, and Slovakia). ${ }^{87}$

Behind Rosatom's aggressive marketing is the Kremlin's awareness of the need to diversify the Russian economy away from oil and gas (these account for nearly half of the state's revenues and two-thirds of the country's exports). ${ }^{88}$ While Russia's industrial sectors have lost their competitiveness due to the Dutch disease, the failure to attract FDI, insufficient human capital, sanctions over Crimea, and the rapid rise of Asian economies as new industrial powerhouses, the export of reactors is one of the few competitive non-hydrocarbon industries that Moscow can bank on. ${ }^{89}$ Added to this is its ambition to restore its global geopolitical influence relative to the USA and NATO (if latently) which has been lost since the demise of the Soviet Union. ${ }^{90}$ For this reason, Rosatom receives the state's full support, which has enabled the company to make competitive financial offers to emerging countries in search of nuclear power under budget constraints. ${ }^{91}$ Russia's additional advantage is the

\footnotetext{
85 Lippman 2012: 121-2; Baklitsky 2013: 27; World Nuclear Association, 'Nuclear Power in Saudi Arabia', January 2016.

86 Ramana and Mian 2016.

${ }^{87}$ World Nuclear Association, 'Nuclear Power in Russia', June 2016.

88 US Energy Information Administration, 'Russia', 28 July 2015.

${ }^{89}$ Gustafson 2012; 'Dependency on Commodities: What Vlad Can Learn from Chad', The Economist, 10 January 2015 ; Gheorghe 2015.

90 Gheorghe 2015.

91 Baklitsky 2013; Adams 2014; 中野 2015.
} 

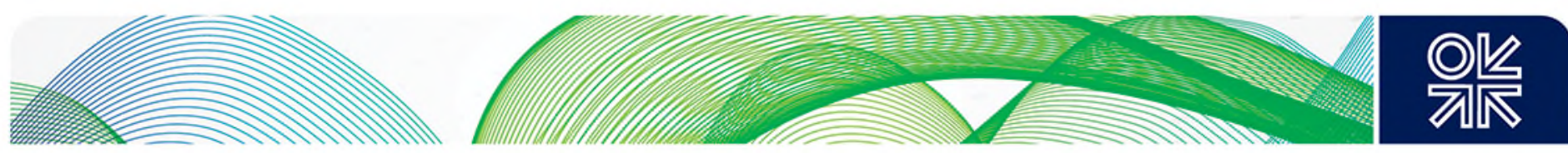

presence of rich uranium reserves in the country; this enables it to offer front-end fuel cycle services to its customers. ${ }^{92}$

In spite of the precarious relations between Russia and the GCC countries seen in recent years due to their disagreement over Syria, Rosatom has been seeking opportunities in the GCC ENET market. The UAE signed a nuclear cooperation agreement with Russia in December 2012 to import fuel from Russia for its Barakah nuclear plant. ${ }^{93}$ Saudi Arabia also signed a nuclear accord with Russia, in June 2015; this was followed by the first meeting of the Saudi-Russian joint nuclear coordination committee in Riyadh in March 2016, which was attended by delegates from KACARE and Rosatom. ${ }^{94}$ Rosatom also opened an office in Dubai in March 2016. ${ }^{95}$

\section{GCC-East Asia Relations in the Field of Renewable (Solar) Energy}

Renewable energy consists of several sources of energy such as solar, wind, waves, and geothermal. This paper focuses on solar, which is rapidly making inroads into the global energy market today. At the end of 2015, the power generation capacity of solar was estimated to be $232 \mathrm{GW}$, while that of nuclear was $382 \mathrm{GW} .{ }^{96}$ According to an IEA prediction, global solar power capacity will surpass that of nuclear within a decade. While the countries hosting large solar power capacities have so far mainly been OECD ones (except for China), the centres of solar investment are shifting to the developing world. ${ }^{97}$

Table 3: The Top 10 Solar Energy Countries in the World (2015)

\begin{tabular}{|c|c|c||c|c|c|}
\hline No. & Country & Capacity & No. & Country & Capacity \\
\hline 1 & China & $43.5 \mathrm{GW}$ & 6 & UK & $8.8 \mathrm{GW}$ \\
\hline 2 & Germany & $39.7 \mathrm{GW}$ & 7 & France & $6.6 \mathrm{GW}$ \\
\hline 3 & Japan & $34.4 \mathrm{GW}$ & 8 & Spain & $5.4 \mathrm{GW}$ \\
\hline 4 & USA & $25.6 \mathrm{GW}$ & 9 & Australia & $5.1 \mathrm{GW}$ \\
\hline 5 & Italy & $18.9 \mathrm{GW}$ & 10 & India & $5.0 \mathrm{GW}$ \\
\hline
\end{tabular}

Source: International Energy Agency

In the past, solar energy was considered to be a cost-ineffective source of energy. The tide, however, began changing in the mid-2000s. First, the rise of the global climate change regime following the Kyoto Protocol, coming into force in 2005, began making a 'green economy' the norm in the global political economy. Second, large-scale production of solar photovoltaic (PV) modules using crystalline silicon (c-Si) technology began in China around the same time. The rise of Chinese PV production created oversupply in the global PV market, resulting in an 80 per cent drop in the price of $\mathrm{PV}$ between 2010 and $2015 .^{98}$

Today, the levelized cost of energy (LCOE) for solar power is less than US $\phi 10$ per kilowatt hour $(\mathrm{kWh})$. According to a recent report by IRENA, its LCOE is now lower than oil-based power when the price of oil is above US $\$ 40$ per barrel. ${ }^{99}$ Downward price competition was unleashed by the announcement in November 2014 of the record lowest price of US $\phi 5.85$ per kWh for the $200 \mathrm{MW}$ Phase II of Dubai's Mohammed bin Rashid Al Maktoum Solar Park, and this was followed by even

\footnotetext{
92 Baklitsky 2013; World Nuclear Association, 'Russia’s Nuclear Fuel Cycle', 14 June 2016.

93 'UAE and Russia Sign Landmark Nuclear Fuel Deal', The National, 19 December 2012.

94 'Pacts Boost KSA-Russian Relations', Arab News, 19 June 2015; 'KSA, Russia Discuss Nuclear Cooperation', Arab News, 18 March 2016

95 'Rosatom of Russia Opens Office in Dubai', Gulf News, 5 April 2016.

96 'Global CSP Capacity Forecast to Hit 22 GW by 2025', CSP Today, 20 September 2015; International Energy Agency 2016:

7; International Atomic Energy Agency, 'Nuclear Power Capacity Trend'.

97 'Solar Energy: The New Sunbathers', The Economist, 16 April 2016.

98 'Solar Energy: Follow the Sun', The Economist, 16 April 2016.

${ }^{99}$ International Renewable Energy Agency 2016: 47.
} 

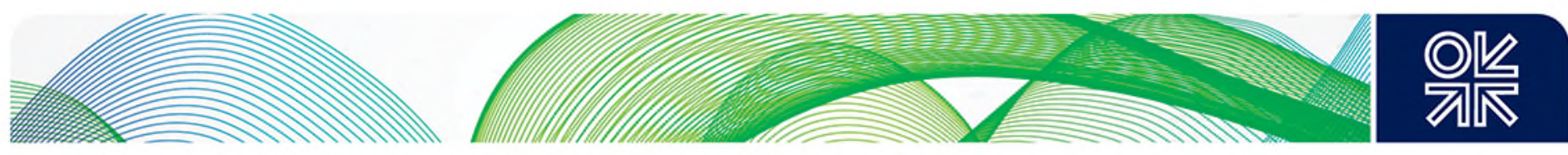

cheaper prices in other places in the world. Dubai's Solar Park again achieved the record by announcing US $\$ 2.99$ per $\mathrm{kWh}$ for its $800 \mathrm{MW}$ Phase III in June 2016. ${ }^{100}$ While some doubt the project's profitability with these low prices, others address the GCC operators' advantage - enjoying access to low-interest loans from local financial institutions - that enables these low prices to be achieved. 101

\subsection{East Asian ERET Industry}

\section{China}

During the early stage of its development, in the early 2000s, the global PV market was dominated by the traditional industrial triad: Japan, Germany, and the USA. Then, in the mid-2000s, technological changes, especially the standardization of $\mathrm{C}-\mathrm{Si} \mathrm{PV}$ manufacturing technology, enabled Chinese producers to launch low-cost PV production. ${ }^{102}$ Capitalizing on their advantages - such as costcompetitiveness and economies of scale - Chinese PV production mushroomed, making China the world's largest PV-producing country in 2008. China today accounts for over 60 per cent of global PV production, ${ }^{103}$ and six Chinese firms were among the 10 largest PV producers in the world in 2015: Trina (天合), Canadian (阿特斯), Jinko (晶科), JA (晶澳), Yingli (英利), and SFCE (顺风清洁). 104

Unlike the history of the traditional industrial triad, China's solar industry initially developed in an export-oriented manner, responding to the growth of European solar markets. The Chinese government, promoting the technological upgrading of the country's industrial production with the slogan of 'self-innovation' (自主创新), provided solar start-ups with a variety of financial support such as grants for R\&D, low-interest loans, and tax credits. ${ }^{105}$ As the rise of Chinese PV production soon resulted in excessive production capacity in the global PV industry, the USA and the EU began imposing anti-dumping duties on Chinese PV in 2012 and 2013 respectively, in order to protect their domestic PV industry. These measures caused substantial damage to the export-oriented Chinese PV industry, resulting in the closure of nearly a third of Chinese PV firms after 2011. ${ }^{106}$

China's domestic solar market began rapidly growing thereafter, supported by a feed-in tariff (FIT) implemented by the Chinese government in 2011. China's installed PV capacity, which was only $1 \mathrm{GW}$ in 2011, made a great leap forward to $43.5 \mathrm{GW}$ in 2015 , making it the world's top country in terms of installed PV capacity. ${ }^{107}$ The Chinese government plans to more than triple the country's solar power capacity to $143 \mathrm{GW}$ by $2020,{ }^{108}$ in order to achieve the target set by its Energy Development Strategic Action Plan (2014): to increase the share of non-hydrocarbon sources in the country's energy mix from the current 10 per cent to 15 per cent by $2020 .{ }^{109}$ Beijing also considers solar and other forms of renewable energy to be one of the major pillars of China's economic cooperation diplomacy under its One Belt One Road initiative. ${ }^{110}$

\section{Japan}

Japan used to be the world's largest PV-producing country, accounting for over half of the global PV production in 2004. ${ }^{111}$ Just as in the case of nuclear energy, the Japanese government began its substantial investment in the development of solar energy after the Oil Crisis of 1973, launching the

\footnotetext{
100 'Abu Dhabi's Masdar Picked to Build Solar Plant in Dubai', Bloomberg, 27 June 2016.

101 'How Dubai Will Deliver Sub-6 $\not$ Solar', PV Tech, 19 January 2016.

102 Asano 2014: 164-8.

103 US Energy Information Administration, 'Global Solar Photovoltaic Manufacturing Production Slows in Recent Years', 14 September 2015.

104 'Top 10 Solar Module Manufacturers in 2015', PV Tech, 21 January 2016

105 Puttaswamy and Ali 2015: 2-4.

${ }^{106}$ Wang 2014: 213.

107 International Energy Agency 2016: 14

108 'China to More than Triple Solar Power Capacity in Five Years', Bloomberg, 21 March 2016.

109 'China Unveils Energy Strategy, Targets for 2020', Xinhua, 19 November 2014

110 'Xi's Visit Brings “One Belt and One Road” Cooperation to New Level', China Daily, 22 January 2016.

${ }^{111}$ Asano 2014: 158-9.
} 

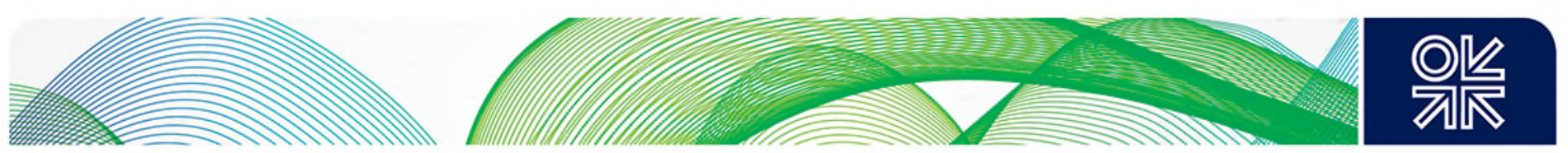

Sunshine Project (サンシャイン計画) for developing solar technology in 1974. Japanese producers developed commercially viable solar modules under this project, enabling Japan to take global leadership in the diffusion of residential-use PV. Nevertheless, due to the rise of Chinese PV production, Japan's share in global PV production declined to just 4 per cent by $2014 .{ }^{112}$ No Japanese firms were among the 10 largest global PV producers in 2015. ${ }^{113}$ Japan's domestic solar market was also overtaken by the rapidly growing European solar markets in the late 2000s.

Following the Fukushima disaster, Japanese citizens, however, began to embrace the use of renewable energy more strongly. The Fourth Strategic Energy Plan (2014) set the target of increasing the share of renewable energy in the country's energy mix from 2 per cent in 2013 to 13.5 per cent by 2020 , and to 20 per cent by $2030 .{ }^{114}$ In order to achieve these targets, the Japanese government began implementing aggressive FIT schemes to make its domestic solar market grow again. Japan is currently the third largest country in terms of installed PV capacity (34.4 GW at the end of 2015) after China and Germany. ${ }^{115}$ Nevertheless, Japanese PV producers have so far found themselves facing tough competition from Chinese PV even in their domestic market, since Japan has not implemented protective measures against Chinese PV like those practised by the USA and the EU. ${ }^{116}$

As it is unlikely that Japan can dramatically recover its share in the global PV market, Japanese firms now need to restructure their business portfolios and contrive strategies for survival. Some Japanese PV producers have been considering relocation of their production abroad, while others plan to shift their focus to EPC projects associated with large-scale solar power plants. ${ }^{117}$ Japanese firms have so far been slow in undertaking EPC projects in foreign markets, partly because Japan's domestic solar market is still growing. Nevertheless, more Japanese firms are likely to find themselves needing to operate globally in the coming years, as the growth of Japan's domestic solar market is expected to peak in 2016 due to the Japanese government's decision to cut the FIT. ${ }^{118}$

\section{South Korea}

In comparison with China and Japan, South Korea's solar industry has, surprisingly, remained marginal. The previous president (Lee) attempted to invigorate the industry by identifying 'green growth' (녹색성장) as one of the major pillars of the country's new growth strategy. In July 2009, South Korea launched the National Strategy for Green Growth (녹색성장국가전략), a long-term strategy in accordance with which five-year plans are made. ${ }^{119}$ Likewise, the Global Green Growth Institute (GGGI) (글로벌녹색성장연구소) was created in Seoul in June 2010 as a research institute to support the planning. The Institute was converted into an international organization in October 2012, and has been serving as an instrument for South Korea's international cooperation diplomacy in the field of renewable energy. ${ }^{120}$

Under the Strategy, the South Korean government began promoting the use of solar power using FIT. ${ }^{121}$ Japan's Fukushima disaster in 2011 also made more South Korean citizens prefer renewable energy to nuclear energy. For instance, the city of Seoul launched the 'One Less Nuclear Power Plant' (원전하나줄이기) campaign in 2012, supporting the installation of rooftop PV to the city's public

\footnotetext{
112 Fraunhofer Institute for Solar Energy Systems 2016: 4.

113 'Top 10 Solar Module Manufacturers in 2015', PV Tech, 21 January 2016.

114 US Energy Information Administration, 'Japan', 30 January 2015; 資源エネルギー庁 2014: 19-22

115 International Energy Agency 2016: 14.

116 'Solar PV Manufacturer Solar Frontier Expanding Globally as Japanese Solar Market Softens', Renewable Energy World, 16 July 2015

'Solar PV Manufacturer Solar Frontier Expanding Globally as Japanese Solar Market Softens', Renewable Energy World, 16 July 2015; 'シャープ、太陽光発電事業の戦略を公表、海外や EPC を強化', 日経テクノロジー, 2 April 2015.

118 'Japan to Hit Solar Peak of 14.3 GW This Year, Finds BNEF', PV Magazine, 18 February 2016.

${ }^{119}$ Choi 2013: 6-7.

${ }^{120}$ Global Green Growth Institute, 'Programs \& History', http://gggi.org/about-gggi/programs-plan-history/ [accessed 30 May 2016]

121 'ROK Wants to Rock the Solar Scene', PV Magazine, January 2011.
} 

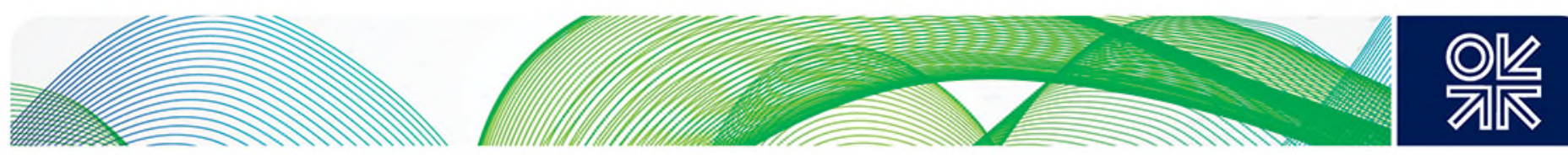

buildings, schools, houses, and commercial buildings. ${ }^{122}$ The Second Basic Energy Plan (2014) targeted an increase in the share of renewable energy in the country's energy mix from the current 1 per cent to 11 per cent by $2035 .{ }^{123}$

Some chaebol conglomerates, like Hanwha Group (한화그룹), have adopted a strategy to leapfrog their PV production through the acquisition of foreign firms. For instance, Hanwha Q Cells, a subsidiary of Hanwha Group, has become the fifth largest PV producer in the world (2015) as a result of the company's acquisition of China's Solarfun (江苏林洋能源) and Germany's Q Cells. ${ }^{124}$ The company currently operates PV manufacturing plants in China and Malaysia with a total capacity of $3.7 \mathrm{GW}$, while it runs R\&D activities in Germany. In June 2015, the company announced the creation of the first large-scale PV manufacturing plant in South Korea, with a capacity of $1.5 \mathrm{GW} .{ }^{125}$

Although the protective measures practised by the USA and the EU against Chinese PV have created a degree of advantage to PV production in South Korea, ${ }^{126}$ the prospects for South Korea's emerging PV industry are not all bright. Because of the oversupply in the global PV market, some South Korean firms, like Japanese ones, have already given up investing in this sector while others have been shifting their investment focus to production in Southeast Asian countries and to EPC projects. ${ }^{127}$

\subsection{GCC ERET Market}

Solar energy is increasingly considered by GCC policy makers as a promising source of energy for power production. The Arabian Peninsula, with over 3,000 hours of sunlight annually, is one of the most sunshine-rich places in the world. ${ }^{128}$ Although the total solar power capacity of the GCC countries was only $163 \mathrm{MW}$ at the end of $2015,322 \mathrm{MW}$ are currently under implementation, and $1,405 \mathrm{MW}$ are expected to be tendered in 2016, according to the Dubai-based Middle East Solar Industry Association. ${ }^{129}$

The UAE, with $328 \mathrm{MW}$ of the existing and upcoming capacity and 1,150 MW to be tendered in 2016, has been leading the field. Saudi Arabia and Kuwait have also begun launching larger solar projects, while Qatar announced its ambitious plan to develop 1,000 MW of solar power capacity in February $2016 .{ }^{130}$

Table 4: GCC and Arab Countries' Installed Solar Power Capacity (Unit: MW)

\begin{tabular}{|c|c|c|c|}
\hline Country & Operational & Under Execution & Tendered in 2016 \\
\hline The UAE & 128 & 200 & 1150 \\
\hline Saudi Arabia & 23 & 62 & 170 \\
\hline Kuwait & 12 & 60 & 85 \\
\hline GCC & 163 & 322 & 1405 \\
\hline \hline Egypt & 70 & 1800 & 250 \\
\hline Jordan & 30 & 320 & 245 \\
\hline Morocco & 160 & 350 & 2000 \\
\hline Algeria & 270 & 80 & \\
\hline
\end{tabular}

Source: Middle East Solar Industry Association

\footnotetext{
122 ‘One Less Nuclear Power Plant', The Korea Times, 23 September 2014

123 산업통상자원부 2014.

124 'Top 10 Solar Module Manufacturers in 2015’, PV Tech, 21 January 2016.

125 'Hanwha Q Cells to Build 1.5 GW Solar Cell Plant in South Korea', PV Magazine, 1 June 2015

126 'CSUN Opens PV Cell Factory in Korea', PV Magazine, 15 October 2015.

127 'Korea's Cautious Comeback', PV Magazine, March 2013; 'KEPCO's Adventure: KEPCO Wins First Overseas Solar Power

Plant Project', Business Korea, 7 April 2016.

128 Ragette 2003: 13; 'The Gulf's Bright Solar-Powered Future', Al Jazeera, 23 January 2014.

${ }^{129}$ Middle East Solar Industry Association 2016: 4.

130 '1,000 MW Solar Power Firm to Be Set up Soon', The Peninsula, 28 February 2016.
} 

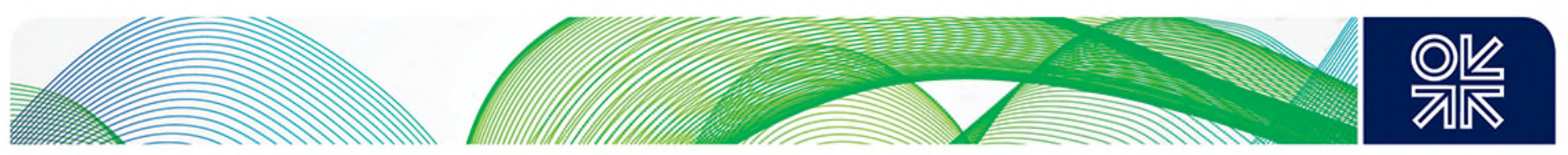

The development of the solar industry in the GCC countries was initially led by institutions with scientific and technological capacity such as Masdar (the UAE), Saudi Aramco (Saudi Arabia), and the Kuwait Institute for Scientific Research (Kuwait). They have launched small- to medium-sized pilot/initial projects by mobilizing their global intellectual and commercial networks. However, partly due to the early stage of its development, leadership in the GCC's solar industry still remains unconsolidated. Multiple local institutions undertaking solar projects have been emerging and exploring their relationships with other players in the field.

One possible long-term scenario is that the utility authority and monopoly of each GCC country (such as DEWA in Dubai, ADWEA in Abu Dhabi, and SEC in Saudi Arabia) will be the main players in the field, partnering with foreign and local solar technology firms. This is because solar power plants (those beyond the size of self-sufficiency) must be connected to the grid and have their generated electricity purchased. Thus, once the market is formed, the utility authority and monopoly which owns the grid and is endowed with the right to purchase electricity may start enjoying a greater advantage in implementing projects independently.

\section{The UAE}

The UAE's power demand, which was $27 \mathrm{GW}$ in 2013,131 is expected to surpass $40 \mathrm{GW}$ by $2020 . .^{132}$ The UAE has set the target of producing 25 per cent of the country's power supply through nuclear and renewable energy by 2030 , and is currently studying the feasibility of a 30 per cent target. ${ }^{133}$ Towards this goal, the country aims to achieve a 7 per cent target by 2020. In the solar sector, the emirates of Abu Dhabi and Dubai pursue projects independently, while Sharjah is also currently considering the development of solar power. ${ }^{134}$ Dubai announced in November 2015 an ambitious long-term plan called 'Clean Energy Strategy 2050' (استراتيجية دبي للطاقة النظيفة 2050) which targets the production of 75 per cent of the emirate's power supply through renewable energy by $2050 .{ }^{135}$

The development of solar power in the UAE has been led by Abu Dhabi Future Energy Company (شركة أبوظبي لطاقة المستقبل), a state-owned enterprise. The company, since its creation in 2006, has been known as 'Masdar' (مصدر) ('source'). The initial solar strategy of Masdar was to invest in projects in countries with an established solar sector and absorb knowledge and technology from its joint venture partners. In 2008, Masdar formed a joint venture, Torresol Energy, with Spain's SENER, a firm based in Bilbao. Torresol Energy was 40 per cent owned by Masdar and 60 per cent by SENER. The company launched a 20 MW CSP solar plant in Seville in October 2011, and two other 50 MW CSP plants in Cadiz in February 2012.136

Masdar's first solar project in the UAE was a small-scale $10 \mathrm{MW}$ PV power plant, which it set up in Abu Dhabi in May 2009. ${ }^{137}$ Following this pilot project, the company formed a joint venture with Spain's Abengoa and France's Total for a 100 MW CSP plant in 2010. The joint venture, Shams 1 (شمس 1) ('sun'), was 60 per cent owned by Masdar, 20 per cent by Abengoa, and 20 per cent by Total. (Facing financial hardship, Abengoa sold its stake to Masdar in February 2016 and withdrew from the project.) $)^{138}$ The plant, located in Madinat Zayed (مدينة زايد), was launched in March 2013. In addition, Masdar has been planning a 300 MW PV solar park in Al-Ain since 2011. Its first phase, Noor 1 (نور 1) ('light'), is expected to have a capacity of $100 \mathrm{MW} .139$

\footnotetext{
131 US Energy Information Administration, 'UAE', 18 May 2015.

132 'UAE Poised to Award \$40b Nuclear Contract', Gulf News, 8 September 2009.

133 'UAE Eyes New Clean Energy Generation Target by 2030', The National, 20 January 2016.

134 'Sharjah in Talks with Chinese on Solar Deal as Part of Broader Trade Push', The National, 7 December 2015.

135 'Dubai Clean Energy 2050 Launched', Gulf News, 28 November 2015.

136 'Masdar, SENER Commission Spain's Torresol CSP Plant', Power Engineering, 25 May 2011; 'Spain's Gemasolar 24/7

Power Plant', Clean Technica, 8 October 2011; 'Twin Solar Thermal Plants Commerce Operation in Spain', Clean Technica, 6

February 2012.

137 'Masdar City's 10-MW Solar PV Power Plant Activated', PV Tech, 1 June 2009.

138 'Abengoa Sells Shams Power Company Stake to Masdar', The National, 8 February 2016.

139 'UAE Can Save Billions with Solar Energy, Irena Report Says', The National, 7 April 2015.
} 

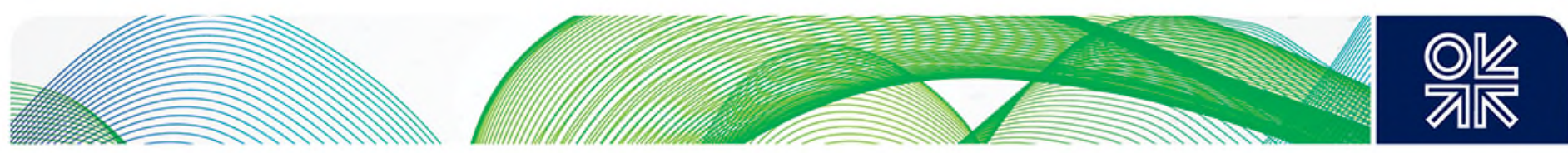

Masdar also initially planned the production of solar modules in the UAE. For this purpose, it invested in a small thin-film solar module manufacturing plant in Ichtershausen in Germany. The plant opened in 2009 with a targeted production capacity of $70 \mathrm{MW}$. 140 The plant supplied modules to some small solar projects such as the $11.7 \mathrm{MW}$ solar farm near the plant (sold to the private equity firm CEE in 2013), ${ }^{141}$ and a $6 \mathrm{MW}$ solar park in Luckenwalde that Masdar had constructed with Beck Energy $\mathrm{GmbH}$ (today's Belectric) in 2011. ${ }^{142}$ Nevertheless, the rise of cost-competitive Chinese PV producers and the oversupply in the global PV market thereafter made PV production in the UAE unrealistic. In January 2011, Masdar decided to abandon the plan, ${ }^{143}$ and its German plant was closed at the end of $2014 .^{144}$

So far, Masdar has been partnering with Western firms for solar projects, but it has also been seeking cooperation with East Asian firms and institutions. Since 2011, South Korea's GGGI has had a regional office at Masdar City (مدينة مصدر), a renewable energy hub in Abu Dhabi developed by Masdar (which also hosts the headquarters of IRENA). ${ }^{145}$ In January 2012, Masdar and Development Bank of Japan (日本政策投資銀行)，a state-owned bank，agreed to seek co-investment in renewable energy projects in OECD countries. ${ }^{146}$ In February 2014, Masdar also signed a memorandum of understanding with Japan Bank for International Cooperation (国際協力銀行), another state-owned bank, for co-investment in the field of renewable energy. ${ }^{147}$ Masdar also expressed interest in seeking opportunities for cross-investment with Chinese firms in December 2015. ${ }^{148}$

Following Masdar, the Abu Dhabi Water and Electricity Authority (ADWEA) (هيئة مياه وكهرباء أبوظبي) announced its entry into the solar sector in December 2015. ADWEA plans to create a $350 \mathrm{MW}$ PV solar park in Sweihan (سويحان). In April 2016, ADWEA pre-qualified 34 bidders for the project. Among them, the following eight firms and consortiums were reportedly qualified to be in 'Category $A$ ' (allowing them to bid on becoming a main operator of the project): EDF (France); Enel (Italy); Engie (France); First Solar (USA); KEPCO (South Korea); RWE and Belectric (Germany); Solar Reserve (USA); Total (France) and Sun Power (USA). ${ }^{149}$

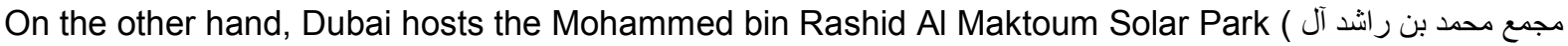
(مكتوم للطاقة الثمسية (سيح الدحل). The Park, located in Seih al-Dahal is operated by the Dubai Electricity and Water Authority (DEWA) (هيئة كهرباء ومياه دبي), which currently aims at 5 GW capacity by 2030.150 Following the small-scale 13 MW Phase I, developed by First Solar, a US firm, in 2013, its 200 MW Phase II is currently under implementation by a consortium of Spain's TSK Group and Saudi Arabia's ACWA Power. Phase II is expected to be completed by 2017. ${ }^{151}$

In June 2016, the Park's 800 MW Phase III was awarded to a consortium led by Masdar, Spain's Fotowatio Renewable Ventures (owned by Saudi Arabia's Abdul Latif Jameel), and Gransolar Group. ${ }^{152}$ Other bidders were China's Jinko Solar, a consortium of ACWA Power and First Solar, a consortium of Japan's Marubeni (丸紅) and France's Engie, and a consortium of France's EDF and Qatar's Nebras Power (نبراس للطاقة).153

\footnotetext{
140 'Masdar Opens Photovoltaic Plant in Germany', Gulf News, 21 August 2008.

141 'Masdar PV Sells 11.7 MW Thin-Film Solar Farm', PV Tech, 20 January 2014.

142 'Germany: Masdar and Beck Complete 6 MW Solar Park', PV Magazine, 17 January 2011.

143 'Masdar PV Abandons Plans for UAE Solar Manufacturing Hub', Renewable Energy Focus, 13 January 2011.

144 'Masdar PV to Shut down Production in Germany', PV Magazine, 27 May 2014.

145 'Masdar City Signs Korean Green Agency as Tenant', The National, 8 July 2011.

146 'Masdar, Devt Bank Japan to Invest in Renewables', Reuters, 16 January 2012.

147 'Masdar Signs MoU with JBIC to Accelerate Renewable Energy Technologies', Gulf News, 26 February 2014

148 'Chinese Investment to Spur Middle East Renewable Energy Ambitions', The National, 6 December 2015.

149 'First Solar, Enel, and EDF among Elite Bidders for Abu Dhabi Solar Project', The National, 27 April 2016.

150 'Dewa Sets Record-Low Target for Third Phase of Mohammed bin Rashid Al Maktoum Solar Park', The National, 27

December 2015.

151 'Dewa Set to Start Work on Second Phase of Mohammed bin Rashid Al Maktoum Solar Park', The National, 19 July 2015.

152 'Abu Dhabi's Masdar Picked to Build Solar Plant in Dubai', Bloomberg, 27 June 2016.

153 'Third Phase of Dubai's DEWA Solar Project Attracts Record Low Bid of US 2.99 cents/kWh', PV Magazine, 2 May 2016.
} 

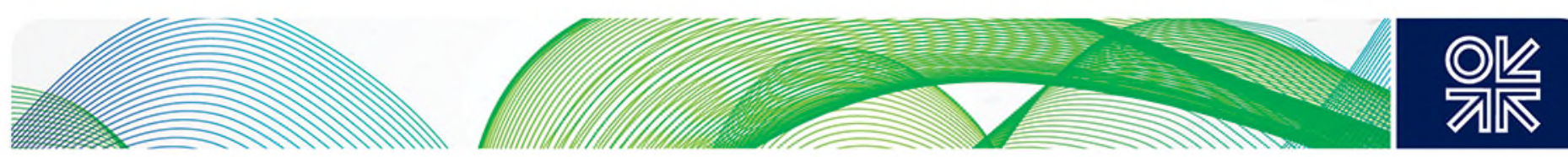

The rise of solar power projects in the UAE has also resulted in the emergence of local solar EPC firms. For instance, Enviromena, a private firm headquartered in Abu Dhabi, undertook Masdar's $10 \mathrm{MW}$ pilot PV project. ${ }^{154}$ Enviromena has also implemented small-scale projects in other countries in the region such as Kuwait, Qatar, Oman, Egypt, and Jordan, with a total capacity reaching $70 \mathrm{MW} .{ }^{155}$ Having accumulated know-how and experience through these projects, the company was awarded its first mega solar project in December 2015, a $100 \mathrm{MW}$ solar power plant in Jordan, with Spain's TSK Group. ${ }^{156}$

On the other hand, Z-One Holding, an investment start-up in the field of solar energy headquartered in Dubai, is eyeing Chinese firms for cooperation. In January 2016, the company announced the formation of a joint venture with China Sunergy (中电电气光伏), a firm based in Nanjing, to co-market PV produced by China Sunergy and to offer PV-related services in the MENA region. ${ }^{157}$

Table 5: Major Solar Power Projects in the UAE

\begin{tabular}{|c|c|c|c|c|c|}
\hline & Operator & Capacity & Status & EPC & $\begin{array}{l}\text { Module } \\
\text { supplier }\end{array}$ \\
\hline 1. Masdar PV Plant & Masdar & $10 \mathrm{MW}$ & $\begin{array}{l}\text { Completed } \\
\text { (May 2009) }\end{array}$ & Enviromena (UAE) & $\begin{array}{l}\text { Sun Tech } \\
\text { (China); First } \\
\text { Solar (USA) }\end{array}$ \\
\hline $\begin{array}{l}\text { 2. Shams 1 CSP } \\
\text { Plant }\end{array}$ & $\begin{array}{c}\text { Masdar, } \\
\text { Total, } \\
\text { Abengoa* }\end{array}$ & $100 \mathrm{MW}$ & $\begin{array}{c}\text { Completed } \\
\text { (March } \\
2013 \text { ) }\end{array}$ & Abengoa (Spain) & $\begin{array}{l}\text { Abengoa } \\
\text { (Spain); First } \\
\text { Solar (USA) }\end{array}$ \\
\hline $\begin{array}{l}\text { 3. Mohammed bin } \\
\text { Rashid Al } \\
\text { Maktoum Solar } \\
\text { Park Phase I (PV) }\end{array}$ & DEWA & $13 \mathrm{MW}$ & $\begin{array}{c}\text { Completed } \\
\text { (October } \\
2013 \text { ) }\end{array}$ & First Solar (USA) & $\begin{array}{l}\text { First Solar } \\
\text { (USA) }\end{array}$ \\
\hline $\begin{array}{l}\text { 4. Mohammed bin } \\
\text { Rashid Al } \\
\text { Maktoum Solar } \\
\text { Park Phase II (PV) }\end{array}$ & DEWA & $200 \mathrm{MW}$ & $\begin{array}{l}\text { Under } \\
\text { execution } \\
\text { (operational } \\
\text { by 2017) }\end{array}$ & $\begin{array}{l}\text { ACWA Power (Saudi } \\
\text { Arabia); TSK (Spain) }\end{array}$ & $\begin{array}{l}\text { First Solar } \\
\text { (USA) }\end{array}$ \\
\hline $\begin{array}{l}\text { 5. Mohammed bin } \\
\text { Rashid Al } \\
\text { Maktoum Solar } \\
\text { Park Phase III } \\
\text { (PV) }\end{array}$ & DEWA & $800 \mathrm{MW}$ & $\begin{array}{l}\text { Under } \\
\text { execution } \\
\text { (operational } \\
\text { by 2020) }\end{array}$ & $\begin{array}{c}\text { Masdar (UAE); } \\
\text { Fotowatio Renewable } \\
\text { Ventures (Spain/Saudi } \\
\text { Arabia); Gransolar } \\
\text { Group (Spain) }\end{array}$ & \\
\hline 6. ADWEA PV Plant & ADWEA & $350 \mathrm{MW}$ & $\begin{array}{l}\text { Under } \\
\text { bidding }\end{array}$ & & \\
\hline
\end{tabular}

*Until February 2016; Various sources

\section{Saudi Arabia}

Saudi Arabia's current power generation capacity is estimated to be $58 \mathrm{GW}$. 158 The country's power demand is expected to grow to over $80 \mathrm{GW}$ by 2020.159 Because its sheer size, it is expected that the Saudi Arabian market will be the 'crown jewel' of MENA solar markets, once the industry takes off. ${ }^{160}$ Vision 2030 (رؤية 2030), the Saudi government's new economic blueprint (announced in April 2016), identified renewable energy as one of the major pillars of economic diversification in the Kingdom and set the 'initial target' of producing $9.5 \mathrm{GW}$ through renewable energy (without giving a timeframe); it

\footnotetext{
154 Enviromena, 'Masdar 10 MW Solar Power Plant', http://enviromena.com/profiles/masdar-10-mw-solar-power-plant/ [accessed 6 April 2016].

155 'UAE's Enviromena Sees Sun Shining for Solar Power in MENA Region', Reuters, 21 January 2016.

156 'U.A.E.'s Enviromena, Spain's TSK Win Deal for Jordan Solar Plant', Reuters, 20 December 2015.

157 'China Sunergy Announces Joint Venture with Z-One Holding', PV Magazine, 11 January 2016.

158 'Saudi Arabia's Soaring Domestic Energy Consumption', Gulf News, 2 August 2015.

159 The Kingdom of Saudi Arabia 2016: 74.

${ }^{160}$ Middle East Solar Industry Association 2016: 6.
} 

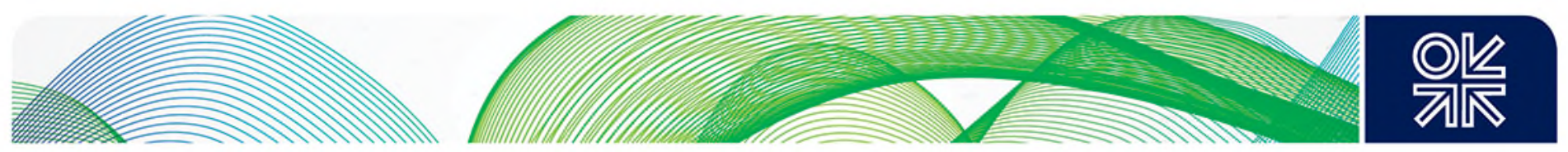

suggested that the 'King Salman Renewable Energy Initiative' (مبادرة الملك سلمان للطاقة المتجددة) would be launched soon. ${ }^{161}$

The National Transformation Programme 2020 (برنامج التحول الوطني 2020), which was disclosed in June following the announcement of Vision 2030, set the target of producing $3.45 \mathrm{GW}$ through renewable energy by 2020.162 (Previously, the Saudi government had planned to supply $41 \mathrm{GW}$, around a third of the projected demand, through solar energy by 2040 , combining $25 \mathrm{GW}$ of CSP and $16 \mathrm{GW}$ of PV. However, this plan now seems to have been abandoned. ${ }^{163}$ )

The use of solar power in the Kingdom has been planned since the creation of KACARE in 2010. Nevertheless, six years later, the country's installed solar power capacity remains at just 23 MW. ${ }^{164}$ The delay in launching the sector has mainly been caused by the lack of appropriate regulatory framework. The mandate initially given to KACARE was ambiguous and its relations with other relevant institutions such as the Ministry of Petroleum and Mineral Resources (MOPMR) and the Saudi Electricity Company (SEC) (الثركة السعودية للكهرباء), a utility monopoly of which 74 per cent is owned by the Saudi government, were not clearly defined. Media reports suggest that KACARE's relationship with MOPMR had become competitive, with the former oil minister Ali Al-Nuaimi (علي reportedly disagreeing with KACARE on the way in which projects were envisioned. ${ }^{165}$

In September 2014, KACARE finally announced its plan to set up five solar power plants, in Qaisumah (القيصومة), Rafha (رفحاء), Wadi al-Duwasir (وادي الدواسر), Mahd al-Dhahab (مهد الذهب), and Shororah (الثرورة). in January 2015, made the future of KACARE uncertain. Only a week after the succession, the new king Salman disbanded the Supreme Council for KACARE. ${ }^{167}$

Under the new regime led by King Salman and his son Deputy Crown Prince Mohammed, new initiatives began appearing. In July 2015, the creation of the country's first solar power plant in Al-Aflaj (الأفلاج) was announced. This 50 MW PV plant will be implemented through cooperation between three institutions: Saudi Technology Development and Investment Company ( الثركة السعودية للتنمية والاستثمار التقني), a company known as 'Taqnia' (تقنية), SEC, and the King Abdulaziz City for Science and Technology (KACST) (مدينة الملك عبدالعزيز للعلوم و التقنية), a governmental research institution. ${ }^{168}$

According to the plan, Taqnia (owned by the Public Investment Fund (صندوق الاستثمارات العامة), a sovereign wealth fund, which has been empowered by the new regime as its investment arm) will construct and operate the plant. Taqnia entered the solar industry in February 2014 with its acquisition of a 50 per cent stake in Sun \& Life, a solar subsidiary of ACWA Holding, which had built Saudi Aramco's 10.5 MW solar car park (mentioned below). ${ }^{169}$ SEC, which will prepare land for the project and purchase electricity from the plant, had previously launched its small-scale $500 \mathrm{~kW}$ pilot solar project on Farasan Island (جزيرة فرسان) in the Red Sea in September 2011. (This project was implemented in cooperation with Showa Shell, a Japanese refinery company in which Saudi Aramco holds a 15 per cent stake. ${ }^{170}$ Showa Shell has a subsidiary for solar business, Solar Frontier (ソーラー フロンティア).) KACST, which will supply PV modules to the plant, has been running its pilot PV assembly plant, with a capacity of 10 MW, in Oyayna (العيينة) since 2010.171

\footnotetext{
161 'Saudi Arabia Announces New Renewable Energy Target with Few Details of Deployment', PV Magazine, 26 April 2016.

162 The Kingdom of Saudi Arabia 2016: 74.

163 'Saudi Arabia Scales Back Renewable Energy Goal to Favor Gas', Bloomberg, 7 June 2016.

${ }^{164}$ Middle East Solar Industry Association 2016: 4.

165 'Disagreements over Scope and Ownership Delay Saudi Solar Projects', Reuters, 8 September 2015.

166 'Solar Energy Plants in Five Regions', Arab News, 22 September 2014.

167 'Massive Cabinet Shake-up', Arab News, 31 January 2015.

168 'Solar Power "Crucial” for KSA', Arab News, 18 October 2015.

169 'State-Owned Firm Acquires 50\% of Saudi Arabia's Sun \& Life', PV Magazine, 4 February 2014.

170 'SEC to Launch First Solar-Powered Electricity Plant', Saudi Gazette, 29 September 2011.

${ }^{171}$ King Abdulaziz City for Science and Technology PV Lab, 'About', www.kacstpvlab.com/about.html [accessed 20 April 2016].
} 

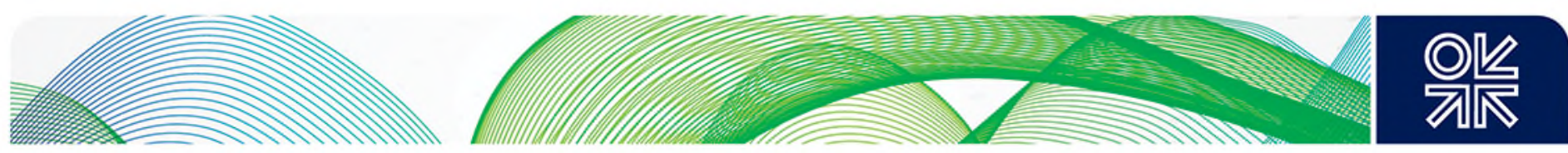

Following this, SEC also announced the creation of an integrated solar combined cycle (ISCC) plant in Duba ضبا) in November 2015. The plant's capacity will be 605 MW, 43 MW of which will be generated through solar power. Spain's Inteq Energia will implement its EPC. ${ }^{172}$ SEC then announced the creation of another ISCC plant in Waad al-Shamal (وعد الثمال) in December 2015. The plant's capacity will be $1,390 \mathrm{MW}, 50 \mathrm{MW}$ of which will be generated through solar power. The USA's GE will implement its EPC. ${ }^{173}$

In order to achieve the goals set by Vision 2030, a major government restructuring was carried out in May 2016. This restructuring unified the administrative functions related to the solar sector (such as energy, industry, and electricity) under the newly created Ministry of Energy, Industry, and Mineral Resources (MOEIMR), which replaced MOPMR. MOEIMR absorbed the administrative functions for industrial policy from the former Ministry of Commerce and Industry and those for electricity policy from the former Ministry of Water and Electricity. In addition, the energy minister, Khalid Al-Falih ( خالد (الفالح), began chairing the board of directors of KACARE and KACST. ${ }^{174}$

This is considered to have paved the way for a full launch of the Saudi solar sector, by solving the problems of institutional ambiguity and fragmentation. Following the government restructuring, SEC announced in June 2016 that it was seeking international investors for two 50 MW PV solar power plants in Al-Jawf (الجوف) and Rafha (رفحاء).175

While the way in which the solar sector's regulatory framework will develop fully from here remains to be seen, Vision 2030 suggested the transformation of Saudi Aramco into an industrial conglomerate and the promotion of public-private partnerships (PPPs) as a new norm in the country's economic diversification process. ${ }^{176}$ Saudi Aramco has been warming up its own solar initiative for years. The company currently hosts the country's largest solar capacity - a $10.5 \mathrm{MW}$ solar car park at its Al-Midra Tower in Dhahran (برج المدرا بالظهران.). The project was completed in December 2012 in cooperation with Japan's Solar Frontier, using its heat-resistant thin-film technology called CIS (copper, indium, and selenide). These $\mathrm{CIS}$ modules recorded 5 per cent higher efficiency in comparison with the c-Si PV module. ${ }^{178}$

Currently, local Saudi solar EPC firms have been waiting for opportunities under PPP. While the development of the sector has been delayed in recent years, Saudi private EPC firms have been acquiring know-how through undertaking solar power projects in other MENA countries. For instance, ACWA Power, a subsidiary of ACWA Holding, co-owned by Abunayyan Group (مجموعة أبو نيان) and AlMuhaidib Group (مجموعة المهيد), is one of the major EPC players in the regional solar EPC markets today. ACWA Power led the consortium for Morocco's Noor 1160 MW CSP Plant with Spain's SENER (launched in February 2016). ${ }^{179}$ It is also currently implementing Dubai's Solar Park 200 MW Phase II with Spain's TSK Group.

Likewise, Abdul Latif Jamil Energy, a subsidiary of the Jeddah-based Abdul Latif Jameel Group (مجموعة عبد اللطيف جميل), a company known for its imports of Toyota vehicles, announced its acquisition of Spain's Fotowatio Renewable Ventures (FRV) in April 2015. ${ }^{180} \mathrm{FRV}$ has implemented solar EPC projects globally, in countries such as Australia, Uruguay, Brazil, and Egypt (their combined capacity

\footnotetext{
172 'SEC Signs SR2.5 bn Deal to Build Green Power Plant', Reuters, 3 November 2015.

173 'Saudi Electric Signs $\$ 980$ mln Waad Al-Shamal Power Plant Deal', Reuters, 30 December 2015.

174 'New Royal Decrees', Arab News, 8 May 2016; 'Vision 2030 Takes Off', Arab News, 8 May 2016.

175 'Saudi Electricity Seeks International Investors for 2 Solar Plants', Arab News, 12 June 2016.

176 'Full Text of Saudi Arabia's Vision 2030', Saudi Gazette, 26 April 2016.

177 The remaining $12 \mathrm{MW}$ consists of smaller projects at universities and research institutes and a solar farm at the King Abdulaziz International Airport in Jeddah (Desert Solar Saudi Arabia, 'Top 10 Solar Projects Saudi Arabia', http://desertsolarsaudiarabia.com/top-10-solar-projects-ksa/ [accessed 20 April 2016]).

178 'Solar Frontier Trumpets Module Performance in MENA Installation', PV Magazine, 5 September 2013.

179 'Morocco Inaugurates 160 MW Solar CSP Plant as First Phase of Noor Complex', PV Magazine, 4 February 2016.

180 'Abdul Latif Jameel Completes FRV Acquisition', PV Magazine, 8 April 2015.
} 

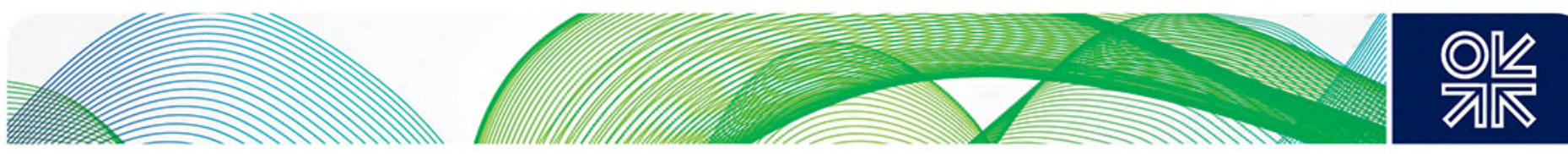

amounts to $532 \mathrm{MW}){ }^{181}$ The company will join the Masdar-led consortium for Dubai's Solar Park 800 MW Phase III.

In addition, solar manufacturing start-ups have also been springing up in the Kingdom. These have been encouraged by the Saudi government's announcement that local content requirements would be implemented in the solar sector. ${ }^{182}$ The National Transformation Programme 2020 set a target of 35 per cent for local content contribution in the renewable energy sector. ${ }^{183}$

The country's first commercial PV inverter assembly plant opened in Riyadh in September 2015. The plant is operated by Shams (شمس), a joint venture firm between Advanced Electronics Company ( شركة الإلكترونيات المتقدمة Desert Technologies (تكنولوجيات الصحراء), a Saudi private firm created in 2012, has acquired PV assembly lines from Germany's Reis Robotics and the USA's EPV Solar, and is currently developing a $95 \mathrm{MW}$ plant in Jeddah. ${ }^{185}$ Saudi Aramco and Showa Shell have also been in talks since October 2011 to create a joint venture to produce solar modules in Saudi Arabia. ${ }^{186}$

Table 6: Major Solar Power Projects in Saudi Arabia

\begin{tabular}{|c|c|c|c|c|c|}
\hline 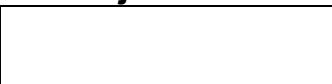 & Operator & Capacity & Status & EPC & $\begin{array}{l}\text { Module } \\
\text { supplier }\end{array}$ \\
\hline $\begin{array}{l}\text { 1. Saudi Aramco } \\
\text { Dhahran Al-Midra } \\
\text { Tower solar car } \\
\text { park }\end{array}$ & $\begin{array}{c}\text { Saudi } \\
\text { Aramco }\end{array}$ & $10.5 \mathrm{MW}$ & $\begin{array}{c}\text { Completed } \\
\text { (December } \\
\text { 2012) }\end{array}$ & $\begin{array}{c}\text { Sun \& Life* } \\
\text { (Saudi Arabia) }\end{array}$ & $\begin{array}{c}\text { Solar } \\
\text { Frontier } \\
\text { (Japan) }\end{array}$ \\
\hline $\begin{array}{l}\text { 2. Taqnia Al-Aflaj } \\
\text { PV plant }\end{array}$ & Taqnia & $50 \mathrm{MW}$ & $\begin{array}{c}\text { Under } \\
\text { execution }\end{array}$ & $\begin{array}{c}\text { Taqnia (Saudi } \\
\text { Arabia) }\end{array}$ & $\begin{array}{r}\text { KACST } \\
\text { (Saudi } \\
\text { Arabia) }\end{array}$ \\
\hline $\begin{array}{l}\text { 3. SEC Duba ISCC } \\
\text { plant }\end{array}$ & SEC & $\begin{array}{l}43 \mathrm{MW} \\
\text { (solar) }\end{array}$ & $\begin{array}{c}\text { Under } \\
\text { execution }\end{array}$ & $\begin{array}{l}\text { Inteq Energia } \\
\text { (Spain) }\end{array}$ & \\
\hline $\begin{array}{l}\text { 4. SEC Waad Al- } \\
\text { Shamal ISCC plant }\end{array}$ & SEC & $\begin{array}{l}50 \mathrm{MW} \\
\text { (solar) }\end{array}$ & $\begin{array}{c}\text { Under } \\
\text { execution }\end{array}$ & GE (USA) & \\
\hline $\begin{array}{l}\text { 5. SEC Al-Jawf PV } \\
\text { plant: }\end{array}$ & SEC & $50 \mathrm{MW}$ & $\begin{array}{l}\text { Under } \\
\text { bidding }\end{array}$ & & \\
\hline $\begin{array}{l}\text { 6. SEC Rafha PV } \\
\text { plant }\end{array}$ & SEC & $50 \mathrm{MW}$ & $\begin{array}{l}\text { Under } \\
\text { bidding }\end{array}$ & & \\
\hline
\end{tabular}

*50\% owned by Taqnia since February 2014 ; Various sources

Kuwait

Kuwait's power demand, which was $12.1 \mathrm{GW}$ in 2013, is expected to grow to $22.5 \mathrm{GW}$ by 2020. Kuwait aims to produce 5 per cent of its power supply through renewable energy by 2020, and 15 per cent by $2030 .{ }^{187}$ In order to achieve these targets, construction of the Shagaya Renewable Energy Park (مجمع الشقايا للطاقة المتجدة) began in December 2015.188 The Kuwait Institute for Scientific Research (KISR) (معهد الكويت للأبحاث العلمية), an operator of the Park, aims to achieve the 1.85 GW solar power capacity by $2030 .{ }^{189}$

\footnotetext{
${ }^{181}$ Fotowatio Renewable Ventures, www.frv.com/ [accessed 1 July 2016].

182 'Saudi Sets out Roadmap for Major Renewable Energy Programme', Reuters, 23 February 2013.

183 The Kingdom of Saudi Arabia 2016: 74.

184 'Saudi Arabia's First PV Inverter Manufacturing Line Opens to Meet Local Requirements', PV Tech, 23 September 2015.

185 'Desert Technologies Exploring Opportunities in Saudi Arabia and Beyond', PV Magazine, 2 July 2013; 'Desert Technologies Plots Saudi Manufacturing Expansions to Capture Domestic Market', PV Tech, 1 July 2015; Desert Technologies, 'Project Portfolio', http://desert-technologies.com/project-portfolio/ [accessed 26 April 2016].

186 'Saudi Aramco Plans Solar Cell Output with Showa Shell', Reuters, 4 October 2011.

187 US Energy Information Administration, 'Kuwait', 24 October 2014.

188 'Kuwait's Shagaya Renewable Energy Park Sees Construction Begin', Bloomberg Business, 14 December 2015.

189 'Kuwait Scales up Investment in Renewables', Utilities-me, 18 November 2015.
} 

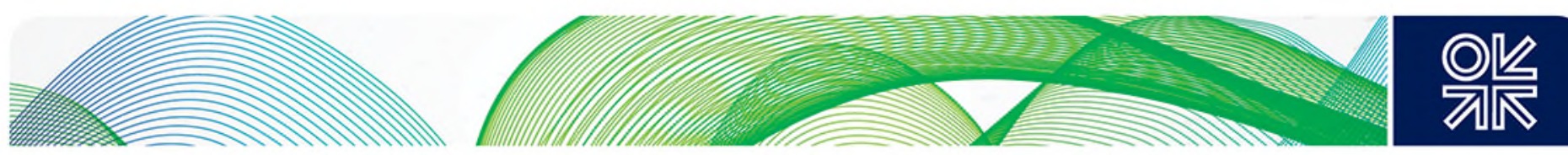

The Park's Phase I will create solar power capacity of $60 \mathrm{MW}$. The $50 \mathrm{MW}$ CSP plant is currently under implementation by Spain's TSK Group. The plant is expected to be connected to the grid by the end of 2017. ${ }^{190}$ In addition, the 10 MW PV plant, also operated by TSK Group, is also currently under implementation. Japan's Solar Frontier will provide $5 \mathrm{MW}$ of its $\mathrm{CIS}$ modules to the plant, and their efficiency will be tested in comparison with c-Si PV modules. ${ }^{191}$

Outside the Shagaya Park, Kuwait Oil Company (KOC) has also been embarking on solar projects. It is currently building a 10 MW PV power plant in Umm Gudair (أم قدير) with Spain's Gestamp. ${ }^{192}$ In addition, the 280 MW Al-Abdaliya ISCC project (محطة العبدلية لتوليد الطاقة الكهربائية باستخدام الطاقة الثمسية), which includes $60 \mathrm{MW}$ solar CSP, is currently awaiting the tendering process. This project is managed by the Partnership Technical Bureau (الجهاز الفني لدراسة المشروعات التنموية والمبادرات), a PPP programme led by the Kuwaiti government. ${ }^{193}$

Table 7: Major Solar Power Projects in Kuwait

\begin{tabular}{|l|c|c|c|c|c|}
\hline & Operator & Capacity & Status & EPC & $\begin{array}{c}\text { Module } \\
\text { supplier }\end{array}$ \\
\hline $\begin{array}{l}\text { 1. Shagaya } \\
\text { Renewable Energy } \\
\text { Park Phase I CSP } \\
\text { plant }\end{array}$ & KISR & $50 \mathrm{MW}$ & $\begin{array}{c}\text { Under } \\
\text { execution } \\
\text { (operational } \\
\text { by 2017) }\end{array}$ & TSK (Spain) & $\begin{array}{c}\text { TSK } \\
\text { (Spain) }\end{array}$ \\
\hline $\begin{array}{l}\text { 2. Shagaya } \\
\text { Renewable Energy } \\
\text { Park Phase I PV } \\
\text { plant }\end{array}$ & KISR & $10 \mathrm{MW}$ & $\begin{array}{c}\text { Under } \\
\text { execution } \\
\text { operational } \\
\text { by 2016) }\end{array}$ & TSK (Spain) & $\begin{array}{c}\text { Solar } \\
\text { Frontier } \\
\text { (Japan) }\end{array}$ \\
\hline $\begin{array}{l}\text { 3. Kuwait Oil } \\
\text { Company Umm } \\
\text { Gudair PV plant }\end{array}$ & $\begin{array}{l}\text { Kuwait Oil } \\
\text { Company }\end{array}$ & $10 \mathrm{MW}$ & $\begin{array}{c}\text { Under } \\
\text { execution }\end{array}$ & Gestamp (Spain) & \\
\hline $\begin{array}{l}\text { 4. Al-Abdaliya ISCC } \\
\text { plant }\end{array}$ & $\begin{array}{l}\text { Partnership } \\
\text { Technical } \\
\text { Bureau }\end{array}$ & $\begin{array}{c}60 \mathrm{MW} \\
\text { (solar) }\end{array}$ & Planned & & \\
\hline
\end{tabular}

Various sources

\subsection{Prospects}

It is likely that the growing GCC solar markets will offer opportunities to East Asian solar firms in the coming years. China, whose leadership in the global PV market is likely to continue, will seek opportunities to export PV modules to upcoming solar projects in the GCC countries. ${ }^{194}$ Chinese PV producers have been experiencing cutthroat competition with each other over foreign markets, given the current oversupply in the global PV market. ${ }^{195} \mathrm{Up}$ to now, the GCC solar sector has been benefiting, both directly and indirectly, from China's exports of low-cost PV modules, which have significantly reduced the cost of solar power and made it competitive vis-à-vis other sources of energy. ${ }^{196}$

On the other hand, Japan and South Korea are likely to seek investment opportunities in solar EPC projects in the GCC countries. Like the transition made by the surviving German solar firms, many Japanese and South Korean solar firms are finding themselves needing to shift their core business away from the production of PV modules towards involvement in EPC projects in which they, with

\footnotetext{
190 'TSK Group to Build 50 MW Solar Plant in Kuwait', PV Magazine, 11 September 2015.

191 'Kuwait to Test Crystalline and CIGS Modules Side-by-Side', PV Magazine, 30 November 2015

192 'KOC to Build Kuwait's Largest Solar Power Plant', Arabian Industry, 5 May 2015.

193 'Kuwait Issues Proposal Request for 60 MW CSP Plant', PV Tech, 13 June 2014.

194 'China Lights up UAE Solar Future', The National, 2 January 2012.

195 'Yingli Fights to Survive as Another Solar King Dethroned', Bloomberg Business, 6 September 2015

196 International Renewable Energy Agency 2016: 47.
} 

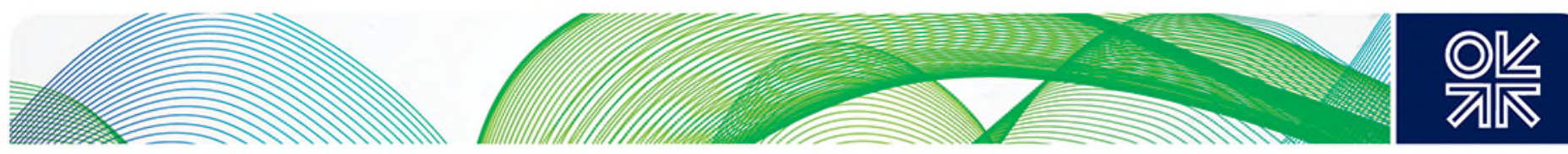

their high technological standards, can exploit their potential to add value. ${ }^{197}$ While Japanese and South Korean firms are currently still benefiting from the growth of their domestic solar markets, they are increasingly find it necessary to explore foreign markets in order to survive in the long run. ${ }^{198}$ They may find opportunities to cooperate with the GCC's solar EPC firms, which are keen on developing know-how through partnering with foreign firms and implementing projects in the GCC and other MENA markets.

EPC projects will also give Japanese and South Korean solar firms the opportunity to supply their own PV modules to these projects. As the supply of heat-resistant CIS modules by Japan's Solar Frontier to projects in Saudi Arabia and Kuwait has shown, there is a potential for Japanese and South Korean firms to develop specialized modules for GCC markets, by capitalizing on their technological advantage. On the other hand, there is also a possibility that GCC solar EPC firms will seek cooperation with Chinese firms, expecting cross-investment between the GCC/MENA and Chinese solar markets.

Nevertheless, East Asian firms are likely to face intense competition from Western solar firms, which have already begun to consolidate their positions in the GCC/MENA solar markets. For instance, Dubai's Solar Park 200 MW Phase II, currently implemented by Spain's TSK Group and Saudi Arabia's ACWA Power, has adopted PV modules supplied by First Solar of the USA. This firm enjoys an early-mover advantage in the UAE - it had previously undertaken the Park's 13 MW Phase I, and also had supplied modules to Abu Dhabi's 100 MW Shams 1 CSP project. ${ }^{199}$

Saudi Arabia's plan to produce PV locally and protect its domestic production through local content requirements is also likely to disappoint Chinese PV producers. While there remains a concern that the local content requirements may pose a barrier to the development of the Kingdom's solar sector, ${ }^{200}$ PV producers in the traditional industrial triad - the USA, Germany, and Japan - may find such protection to be a window of opportunity enabling them to gain access to the Saudi market by forming joint ventures with local Saudi firms. They may even find it providing the opportunity to sell off their PV technologies to Saudi investors as part of their restructuring of business portfolios.

Local content requirements, however, also run the risk of inviting trade disputes. There is even a possibility that the practice will not survive as a legitimate policy, ${ }^{201}$ given that in August 2015 the WTO ruled against India, which had been practising local content requirements to protect its solar industry under the 'Make in India' programme; the WTO advised Delhi to offer a level playing field to both domestic and foreign PV producers. ${ }^{202}$

East Asian solar EPC firms will also face tough competition from Western firms in the GCC's solar markets. Spanish firms already enjoy strong early-mover advantage in the region. As ADWEA's latest tender shows, firms from other Western countries (such as the USA, Germany, France, and Italy) have also been exploring opportunities in GCC markets.

\footnotetext{
197 “太陽光パネルで負けても発電所建設で稼ぐドイツ’, 日本経済新聞, 27 August 2014.

198 “量り空”の太陽電池市場 需要低迷で工場休止、海外事業などに活路’, 産経新聞, 15 February 2015; ‘昭和シェル、ソーラー 子会社はどう戦うのか’, 東洋経済, 7 September 2015.

199 'How Dubai will deliver sub-6ф solar', PV Tech, 19 January 2016.

200 Nachet and Aoun 2015: 22.

201 Steyn and Norman 2012: 4-5.

202 'India's Local Content Requirements Violate Global Trade Rules Finds WTO', PV Magazine, 27 August 2015.
} 

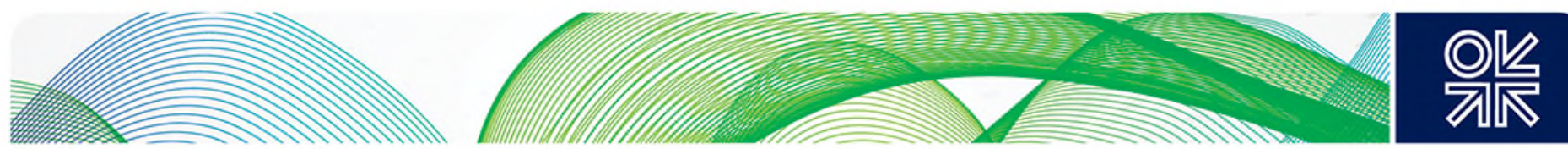

\section{Box: The Spanish Experience}

As the above analyses show, Spanish solar firms, such as Abengoa, TSK Group, and SENER, have been successful in winning contracts for solar projects in the GCC and MENA countries. Spanish firms have also been actively investing in other parts of the world such as Europe, North America, Latin America, and sub-Saharan Africa (especially South Africa). Their high global presence is attributable to two factors.

First, Spanish solar firms are equipped with advanced know-how and technologies in this field due to their early investment in them. ${ }^{203}$ Spain is one of the most advanced countries in the use of renewable energy. Renewable energy covers over half of the country's power production, to which solar energy contributes around 5 per cent. ${ }^{204}$ The Spanish PV market grew quickly in the late 2000s, making Spain the world's second largest country after Germany in installed solar capacity at that time.

Second, the growth of Spain's domestic market slowed down after a period of rapid expansion. Following the global financial crisis in 2008, the Spanish government's decision to cut subsidies for installation of PV resulted in a sharp downsizing of the country's solar sector, which shrank from around 40,000 workers in 2008 to just 5,000 in $2015 .{ }^{205}$ In 2015, Spain only added $56 \mathrm{MW}$ of new solar power capacity; this compares with figures of $15 \mathrm{GW}$ for China, 11 GW for Japan, and $1 \mathrm{GW}$ for South Korea. ${ }^{206}$ It was thus inevitable that Spanish solar firms would explore foreign markets for survival, and this has enabled them to capture early-mover advantage in global EPC markets.

\section{Conclusions}

This paper has attempted to outline the features of emerging GCC-East Asia relationships in the fields of nuclear and renewable (solar) energy. While the two regions are already strongly connected through the trade of hydrocarbon energy sources, they are still largely at the stage of exploring opportunities in bilateral cooperation in the fields of nuclear and solar energy - the energy sources which, combined, are predicted to account for 11.7 per cent of global power production capacity by 2020, according to the IEA's latest estimate. While high complementarity between the two regions in hydrocarbon energy (in the form of consumer-producer relationships) has made their bilateral relations fundamentally reciprocal, up to now the nature of GCC-East Asia relations in nonhydrocarbon energy has not been fully analysed. This paper has aimed to fill that gap in knowledge.

The most important finding of this paper is that countries in the two regions are likely to find highly complementary relations in the fields of nuclear and renewable (solar) energy - although these will be fundamentally different from relations in the field of oil. Unlike oil, there are basically no tradable commodities between the two regions in these fields. The two regions are also geographically too far from each other to consider the possibility of trading produced electricity. Nevertheless, there is one critical factor that places the two regions in a reciprocal relationship: technology. The gap in technological endowment between them makes their relations complementary to each other.

\footnotetext{
203 'Spain: Innovations and International Success', MIT Technology Review, July 2012.

204 'Renewables Account for 54\% of Spain's Electricity Production in April', PV Magazine, 2 May 2013.

205 'Spain Wants to Retake Lead in Renewable Energy', AFP, 13 December 2015.

206 International Energy Agency 2016: 8-10.
} 

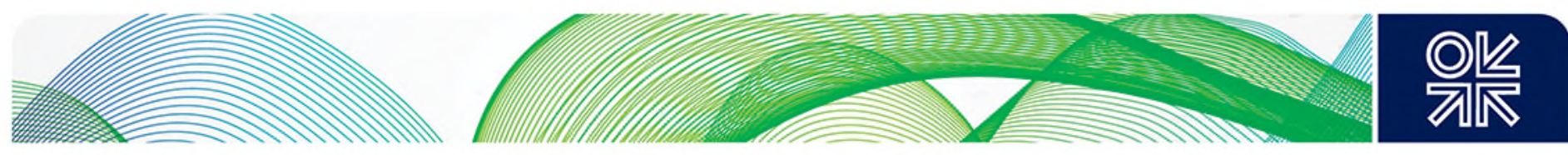

This paper has called that technology ENRET (export-oriented nuclear/renewable energy technology). On one hand, East Asian countries, which had developed technology for nuclear and renewable energy for their own energy security in the past, now explore foreign markets in order to export the technology and keep their industries growing. (The major exception to this is China's PV production; this was initially stimulated by European demand before the recent domestic demand arose.) On the other hand, GCC countries, which have only recently begun fully considering the use of nuclear and renewable energy for power production, are in need of foreign investment to create the technological and industrial base in these fields, and of importing components to set up plants, before becoming capable of running these industries on their own. In this manner, East Asian countries and GCC countries complement each other in the form of ENRET exporter-importer relationships.

There are, however, also differences across the sectors and the countries. In the field of nuclear energy, three East Asian countries are at different stages of development of ENET industry. Japanese nuclear firms already have established ENET capacity, and are in alliance with Western (US and French) firms in marketing their reactor designs globally. South Korea is currently in the process of proving its ENET capacity, with its UAE project being the first case of exporting reactors of its own design. China is not yet a reactor-exporting country: although it has already been making agreements with other states to export reactors, it will take at least several years before it proves its ENET capacity. On the GCC side, the UAE is the only country which has already begun implementing the nuclear project. Saudi Arabia is at the stage of conducting feasibility studies (with South Korea and France). Kuwait has abandoned its plan to use nuclear power. Qatar, Oman, and Bahrain remain at the stage of studying the possibility of nuclear power use.

In the field of solar energy, Chinese producers today dominate the global PV market, posing tough competition to both the traditional Japanese producers and the emerging South Korean ones. The cost advantage of Chinese PV producers and the oversupply in the global PV market have been forcing solar firms in other countries to seek alternative strategies for survival, such as specialization in EPC of solar power plants. While Japanese and South Korean firms are currently still benefiting from the growth of their domestic markets for such business, they are likely to find themselves in greater need of exploring foreign markets as their domestic markets mature. GCC countries, with large-scale solar power projects waiting in line, will offer opportunities to East Asian firms in both PV and EPC.

There are, nevertheless, also barriers to the progress of GCC-East Asia nuclear and renewable energy cooperation. First, East Asian firms compete in GCC markets with firms from other countries that also have a developed competitive ENRET industry. In the field of nuclear energy, Russia has already been emerging as a powerful competitor to East Asian exporters. The ample financial support its state-owned enterprise, Rosatom, receives from the Kremlin gives it a strong advantage in marketing to emerging countries where electricity is supplied at low cost for political reasons. Rosatom is actively targeting the GCC market after winning contracts in other countries in the MENA region such as Iran, Turkey, Jordan, and Egypt.

East Asian firms have also lagged behind Western ones in the GCC solar market. This is partly because their domestic markets are still growing. In contrast, Spanish firms have been most active in the GCC/MENA solar EPC markets because there has been little demand growth at home in recent years. Western solar firms' consolidation of their positions in the GCC markets (capitalizing on their early-mover advantage) is likely to make East Asian firms' entry into these markets less easy, although East Asian solar firms also have their own advantages such as technologies (like the heatresistant solar modules developed by Japanese firms) and Chinese firms' potential offer of cross investment.

Intensifying competition in the global ENRET industry has been turning ENRET markets into 'buyer's markets', where price competition is the norm. East Asian firms need to act fast so they too can capture their early-mover advantage and build up their capacity to establish financial solutions, in order to compete with Western firms which have already been making inroads into the GCC/MENA ENRET markets. 

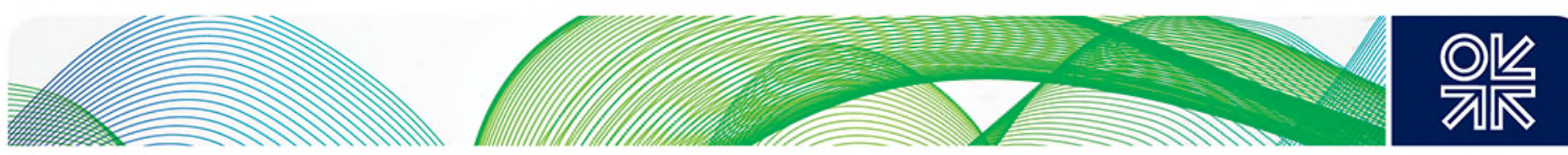

Second, in the long run, a rise in competition between firms within the two regions may also create barriers to cooperation between the GCC and East Asia. This is particularly the case for the solar industry. While East Asian and GCC firms currently find themselves in a complementary relationship due to the technology gap between them, absorption of technology by GCC EPC firms would enable them to implement more projects on their own. As in the case of the petrochemical industry, GCC firms may start competing with foreign firms over market shares globally in the near future. Likewise, while the supply of low-cost Chinese PV offers opportunities to GCC solar projects, Chinese PV exports are also seen by the GCC solar industry as an impediment to the development of their own local PV production. Saudi Arabia will protect local production using local content requirements. This, however, may risk inviting trade disputes with China. 

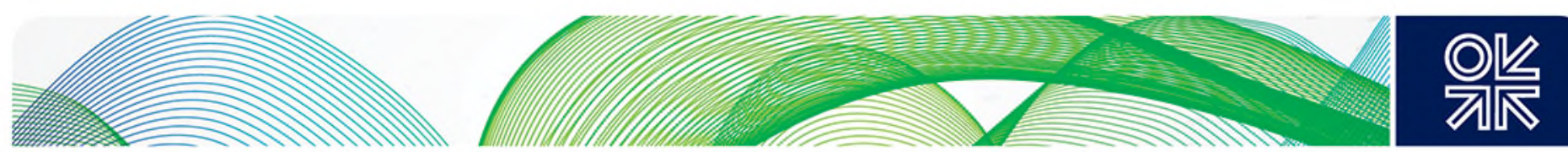

\section{Bibliography}

Adams, Rod. (2014) 'Russia Using Oil Wealth to Finance Nuclear Exports', Atomic Insights, 15 January 2014.

Asano, Kenji. (2014) 'Early Promoter of Solar Photovoltaics: Forty Years of Development of Policy and Technology in Japan', in Espen Moe and Paul Midford (ed.) The Political Economy of Renewable Energy and Energy Security: Common Challenges and National Responses in Japan, China and Northern Europe, London: Palgrave Macmillan.

Bahgat, Gawdat. (2012) 'Energy Security: The United Arab Emirates', Asian Affairs, 43(2): 268-79.

--- (2013) 'The Changing Saudi Energy Outlook: Strategic Implications', The Middle East Journal, 67(4): 565-79.

Bahgat, Gawdat. (ed.) (2015) The Changing Energy Landscape in the Gulf: Strategic Implications, Berlin: Gerlach Press.

Baklitsky, Andrey. (2013) 'Nuclear Energy in the Middle East: Russia's Interests and Role', Security Index, 19(3): 23-32.

Banerjee, Stuti. (2016) 'GCC and BRICs: Exploring the Nuclear Energy Cooperation Route', in Tim Niblock, Degang Sun, and Alejandra Galindo. (ed.) The Arab States of the Gulf and BRICs: New Strategic Partnership in Politics and Economics, Berlin: Gerlach Press.

Calabrese, John. (2015) 'Asia's Role in the Mideast Solar Surge', Middle East Institute, 30 June 2015. Accessible online: www.mei.edu/content/map/asia\%E2\%80\%99s-role-mideast-solar-surge [accessed 1 July 2016].

Center for Strategic and International Studies. (2013) Restoring U.S. Leadership in Nuclear Energy: A National Security Imperative, Lanham, MD: Rowman \& Littlefield Publishers.

Choi, Sang-dae. (2013) The Green Growth Movement in the Republic of Korea: Option or Necessity?, Washington, DC: World Bank Group.

Cigar, Norman L. (2016) Saudi Arabia and Nuclear Weapons: How Do Countries Think about Bomb?, London: Routledge.

Dalton, Toby. and Cha, Minkyeong. (2016) 'South Korea's Nuclear Energy Future', The Diplomat, 23 February 2016.

El-Katiri, Laura. (2012) 'The GCC and the Nuclear Question', Oxford Energy Comment, December 2012.

--- (2013) 'Energy Sustainability in the Gulf States: The Why and the How', Oxford Institute for Energy Studies Paper, MEP 4.

El-Katiri, Laura and Husain, Muna. (2014) 'Prospects for Renewable Energy in GCC States: Opportunities and the Need for Reform', Oxford Institute for Energy Studies Paper, MEP 10.

Fraunhofer Institute for Solar Energy Systems. (2016) Photovoltaics Report, Freiburg: Fraunhofer ISE.

Gheorghe, Eliza. (2015) 'Russia's Role in Turkey's Nuclear Future', Black Sea in Access Denial Age, 7 September 2015.

Gustafson, Thane. (2012) 'How Oil Is Holding Russia Back - and How It Could Save It', Foreign Affairs, 91(6): 83-96.

International Energy Agency. (2015) World Energy Outlook 2015, Paris: OECD/IEA.

--- (2016) 'Snapshot of Global Photovoltaic Markets 2015', Report IEA PVPS T1-29. 

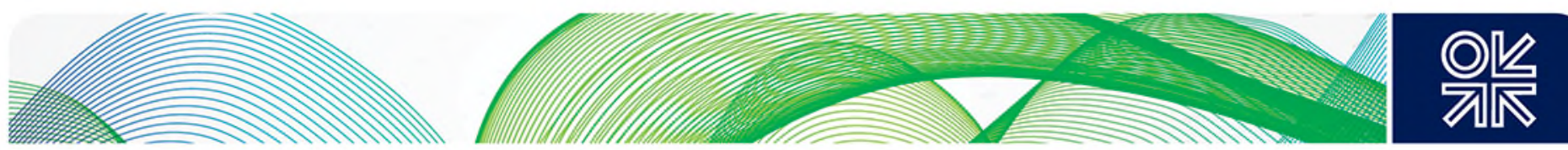

International Institute for Strategic Studies. (2014) 'Nuclear Power: Growing Role of Emerging Nations', Strategic Comments, 20(9).

International Renewable Energy Agency. (2016) Renewable Energy Market Analysis: The GCC Region, Abu Dhabi: IRENA.

Lippman, Thomas W. (2012) 'Saudi Arabia's Nuclear Future', in Mehran Kamrava (ed.) The Nuclear Question in the Middle East, London: Hurst \& Co., 105-24.

Luciani, Giacomo. (1987) 'Allocation vs. Production States: A Theoretical Framework', in Giacomo Luciani and Hazem Beblawi (ed.) The Rentier State, London: Croom Helm, 63-84.

Luomi, Mari. (2012) 'The Economic and Prestige Aspects of Abu Dhabi's Nuclear Program', in Mehran Kamrava (ed.) The Nuclear Question in the Middle East, London: Hurst \& Co., 125-58.

--- (2015) 'The International Relations of the Green Economy in the Gulf: Lessons from the UAE's State-Led Energy Transition', Oxford Institute for Energy Studies Paper, MEP 12.

Middle East Solar Industry Association. (2016) MENA Solar Outlook 2016.

Midford, Paul. (2014) 'The Impact of 3-11 on Japanese Public Opinion and Policy toward Energy Security', in Espen Moe and Paul Midford (ed.) The Political Economy of Renewable Energy and Energy Security: Common Challenges and National Responses in Japan, China and Northern Europe, London: Palgrave Macmillan.

Nachet, Said. and Aoun, Marie-Claire. (2015) The Saudi Electricity Sector: Pressing Issues and Challenges, Paris/Brussels: The Institut Français des Relations Internationals.

Puttaswamy, Nagalakshmi. and Ali, Mohammed Sahil. (2015) 'How Did China Become the Largest Solar PV Manufacturing Country?', Center for Study of Science, Technology \& Policy (CSTEP), Note 2015-02.

Ragette, Friedrich. (2003) Traditional Domestic Architecture of the Arab Region, Fellbach: Edition Axel Manges.

Ramana, M. V. and Mian, Zia. (2016) 'Scrambling to Sell a Nuclear Middle East', Bulletin of the Atomic Scientists, 72(1): 39-43.

Steyn, Clint., and Norman, Marc. (2012) 'Saudi Arabia: The Future Solar Leader', Chadbourne \& Parke LLP, November 2012.

Umbach, Frank. (2014) 'The Energy Security of Japan after Fukushima 3/11', in Espen Moe and Paul Midford (ed.) The Political Economy of Renewable Energy and Energy Security: Common Challenges and National Responses in Japan, China and Northern Europe, London: Palgrave Macmillan.

Vivoda, Vlado. (2014) Energy Security in Japan: Challenges after Fukushima, Surrey: Ashgate.

Wang, Yu. (2014) 'A Review of Renewable Energy Legislation Policies in China', in Espen Moe and Paul Midford (ed.) The Political Economy of Renewable Energy and Energy Security: Common Challenges and National Responses in Japan, China and Northern Europe, London: Palgrave Macmillan.

中野洋一. (2015) ‘世界の原発産業と日本の原発輸出’, 九州国際大学 国際関係論集, 10(1/2).

\section{Official Documents}

The Kingdom of Saudi Arabia. (2016) National Transformation Program 2020.

The People's Republic of China, 国务院办公厅. (2014) 能源发展战略行动计划 ( 2014-2020 年 ).

Japan, 資源エネルギー庁. (2014) エネルギー基本計画. 

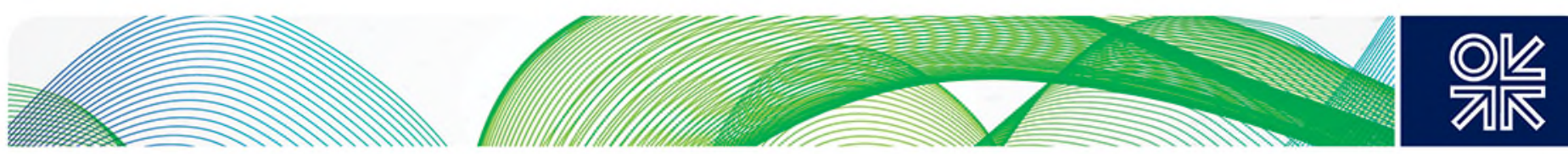

The Republic of Korea, 산업통상자원부. (2014) 제 2 차 에너지기본계획.

\section{Online Data Sources}

International Atomic Energy Agency, Power Reactor Information System, iaea.org/PRIS/.

UN Comtrade Database, comtrade.un.org/data/.

US Energy Information Administration, eia.gov/.

World Bank, World Data Bank, databank.worldbank.org/.

World Nuclear Association, world-nuclear.org/.

\section{Newspapers and Periodicals}

\section{AFP}

Arab News

Arabian Industry

Bloomberg

Business Korea

China Daily

Chosun Ilbo

Clean Technica

CSP Today

The Economist

Emirates 24|7

The Financial Times

Gulf News

The Japan Times

Al Jazeera

The Korea Times

MIT Technology Review

The National

NucNet

The Peninsula

Power Engineering

PV Magazine

PV Tech

Renewable Energy Focus

Renewable Energy World

Reuters

Saudi Gazette

Utilities-me

World Nuclear News

Xinhua

Yonhap News

産経新聞

日本経済新聞

日経テクノロジー

毎日新聞

朝鮮日報 - 日本語版

中央日報 - 日本語版 

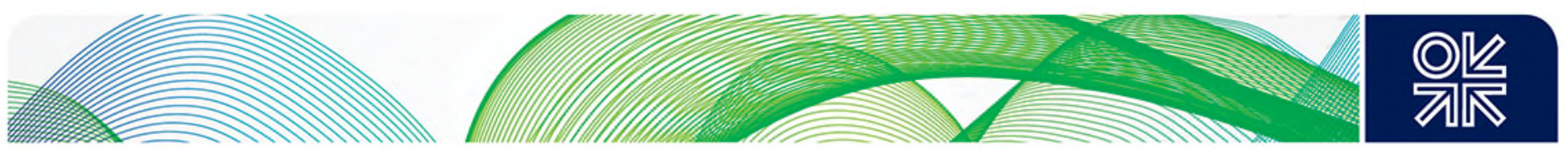

新华网

원자력신문

경향신문 